Art Working: An Institutional Ethnography of the Art World

by

Janna Klostermann

A thesis submitted to the Faculty of Graduate and Postdoctoral Affairs in partial fulfillment of the requirements for the degree of

\title{
Master of Arts
}

in

Applied Linguistics and Discourse Studies

Carleton University

Ottawa, ON

(C) 2015

Janna Klostermann 


\begin{abstract}
This institutional ethnography of the Canadian art world opens with visual artist Beth McCubbin saying, "It's a serious issue in the visual art world how language—or writing — has now been squished on to it." Her experience of disjuncture serves both as a point of entry for the investigation and a critical standpoint from which to explicate the institutional art regime.

Responding to her experience, this study examines the conjunction between language and visual art in the work of artists, in the work of curators and in the wider art world. This inquiry brings into view an increasingly textually and institutionally coordinated art world.
\end{abstract}

Keywords: Canadian art, institutional ethnography, knowledge, work

Reproductions of visual art are included with the kind permission of the artists. Artists retain exclusive copyright of their work. No image may be reproduced without prior written permission from the copyright holder. 


\section{Acknowledgements}

To my supervisors - Richard Darville and Graham Smart — thank you for your intellectually rigorous and delightfully honest support in the process. Richard, thank you for introducing me to (and warning me about!) institutional ethnography. Thank you also for challenging my thinking, grounding my analysis, and asking for humdrum, mundane examples along the way. Graham, thank you for your careful reading, ruthless editing, and willingness to invest in my emerging academic voice. To my examiners - Janna Fox and Gerald de Montigny — thank you for your critical reading and compassionate interrogating. To my mentors south of the border-Elvera Berry, Luan Davis Haggerty, Mary Froehle, Paul Stewart and Evelyn Whitehead — thank you for being in touch with your own politics and willing to instill that in others. You don't just teach; you change the way people see.

To my (art world) participants_-Heather Anderson, Andrea Campbell, Sky Goodden, Petra Halkes, Marika Jemma, Sharon Katz, Fynn Leitch, Virginia Marie, Beth McCubbin, Mary Porter, Anne Renouf, Catherine Sinclair, Jason St-Laurent and Jinny Yu — thank you for your generosity, candor and willingness to contribute in meaningful ways to this project. This one's for you.

To my friends and classmates_-Emily Baker, Sharon Caldwell, Sara Doody, Nina Doré, Jillian Keene, Deb Landry, Kelly Pineault, Steph Mauk, Sandro Marcon and Kim Radford—-thank you for dreaming big, fueling my critiques, and knowing when to grab a drink (or schedule a phone date) along the way. To my family_Mom, Dad, Nanny, Ga and Clairey — thank you for always pushing for comedy and for justice, and for really knowing how to love someone. To my partner-Philip — thank you for sharing this with me (and for contributing to my ever-growing collection of "Shit My Husband Says" one-liners). 


\section{Table of Contents}

Abstract fow

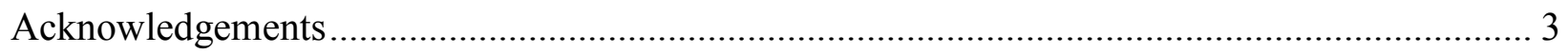

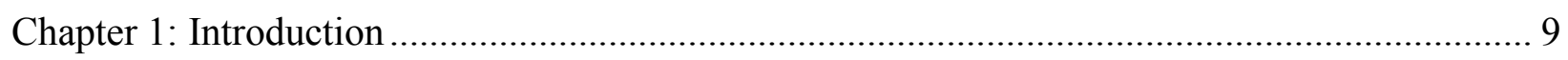

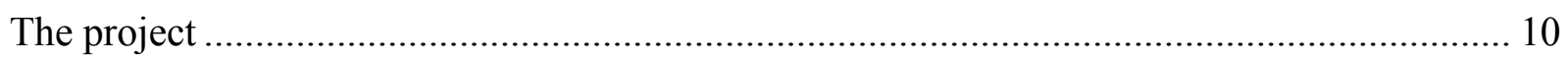

Institutional ethnography ……………….................................................................. 12

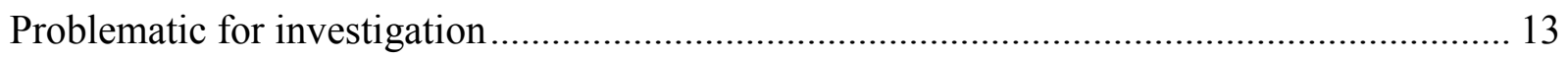

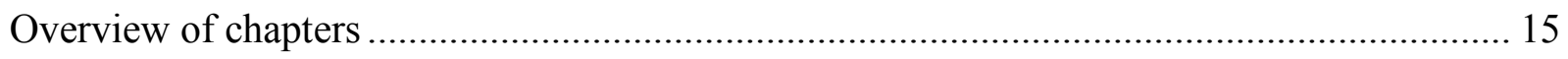

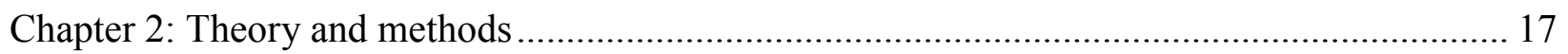

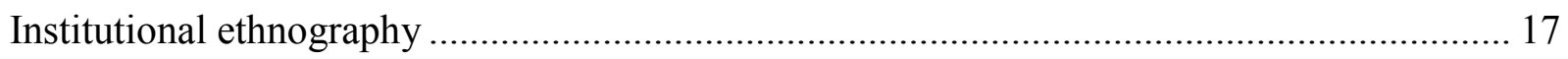

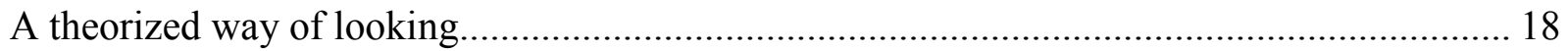

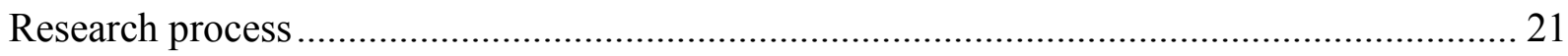

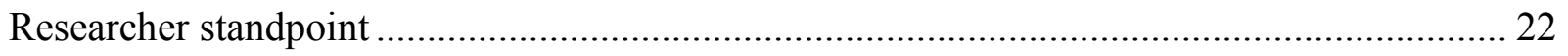

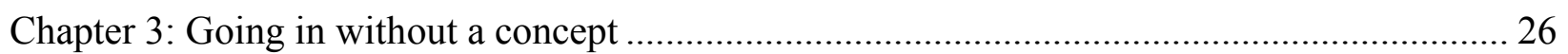

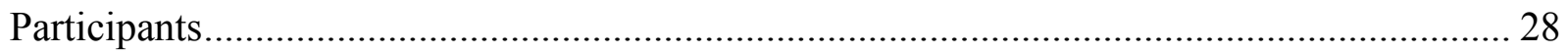

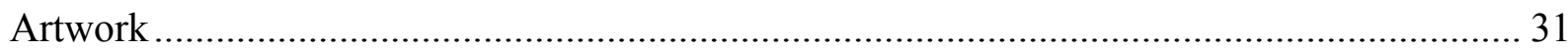

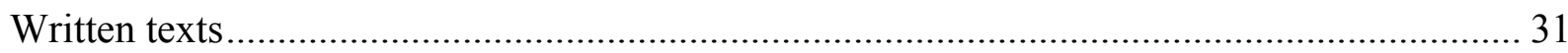

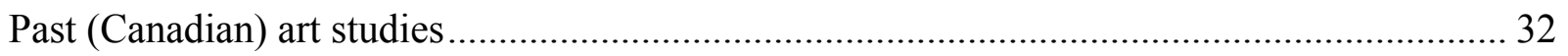

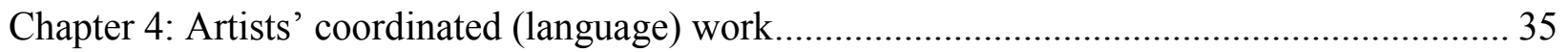

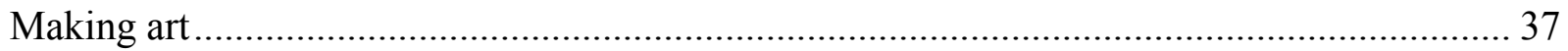


Getting out there

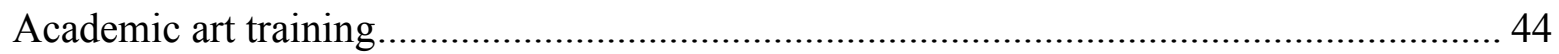

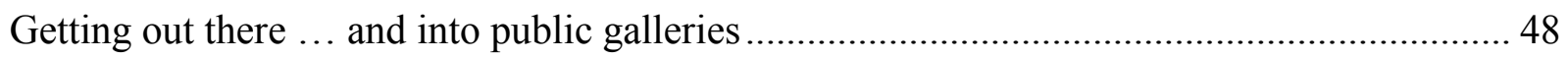

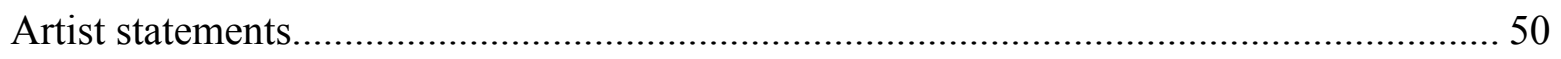

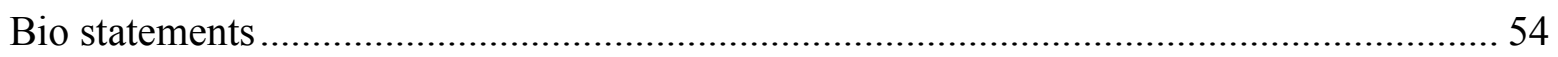

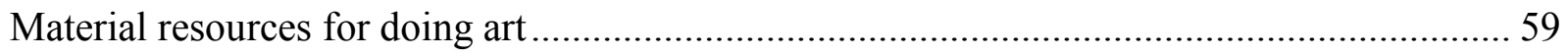

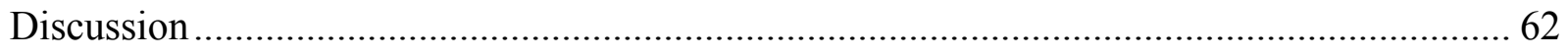

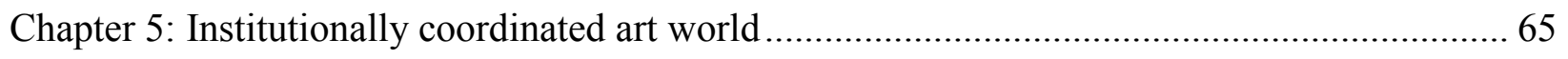

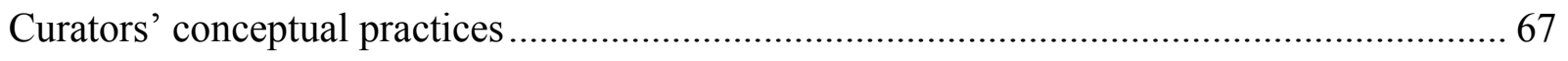

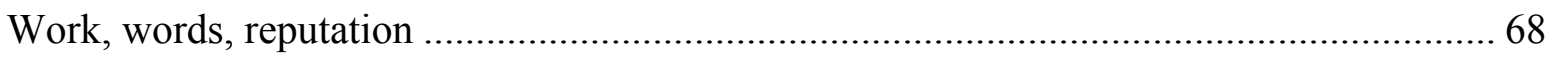

Expanding outwards... funding bodies, audiences, conversations, mandates................... 72

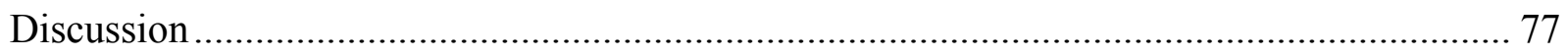

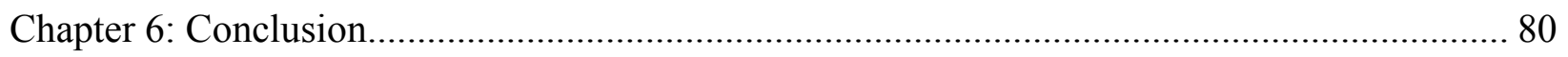

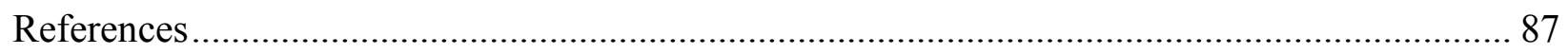

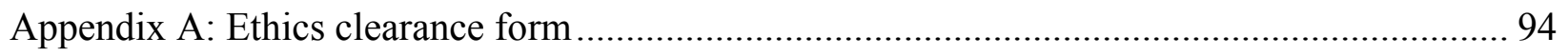

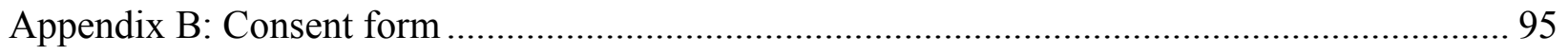

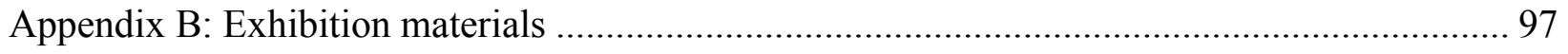




\section{List of Tables}

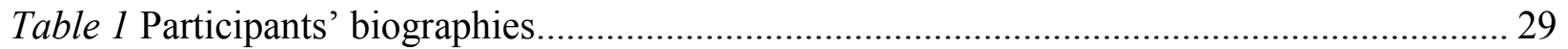

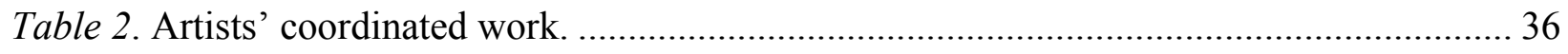

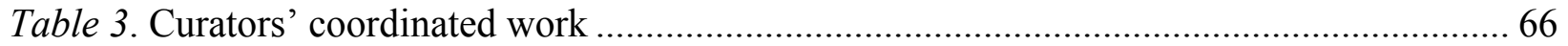




\section{List of Figures}

Figure 1. Beth McCubbin, eternal spirit, 2014, concrete installation at the Sisters of Mount St.

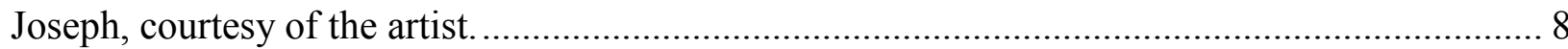

Figure 2. Anne Renouf, Bloodline, 2009, courtesy of the artist.......................................... 16

Figure 3. Petra Halkes. Strip, 2011, 3.5 feet by 10 feet, courtesy of the artist.......................... 25

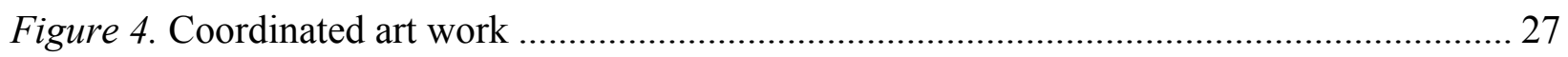

Figure 5. Mary Porter, film still from North End, 2014, digital photo collage animation, courtesy

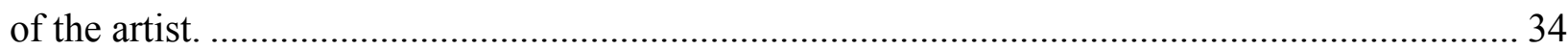

Figure 6. Beth McCubbin, bowls of truisms, 2014, porcelain, stoneware and black clay, glazes

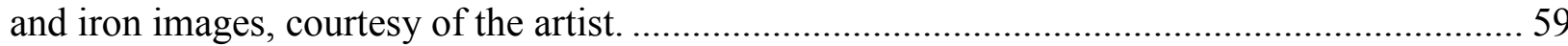

Figure 7. Marika Jemma, Backyard, 2012, photo mural installation with video insert, 12 x 8 feet, composed of 576 individual $4 \times 6$ snapshots taken with 400 iso colour film, representing a 360

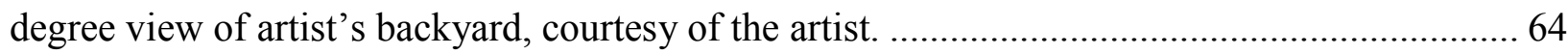

Figure 8. Jinny Yu, Ball; Studio Work Number 37; Ball; Column; Stalker; Painting, Painting, Painting, 2014, various dimension and materials, installed at Ottawa Art Gallery, courtesy of the

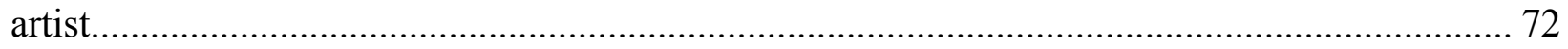

Figure 9. Sharon Katz, Manifest, 2013, installation still image, video projection on handmade

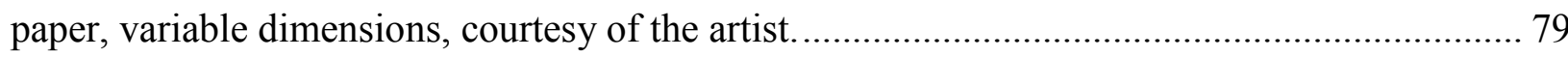

Figure 10. Virginia Marie, Abandoner, 2014, oil on canvas, 18 x 36 inches, courtesy of the artist. 


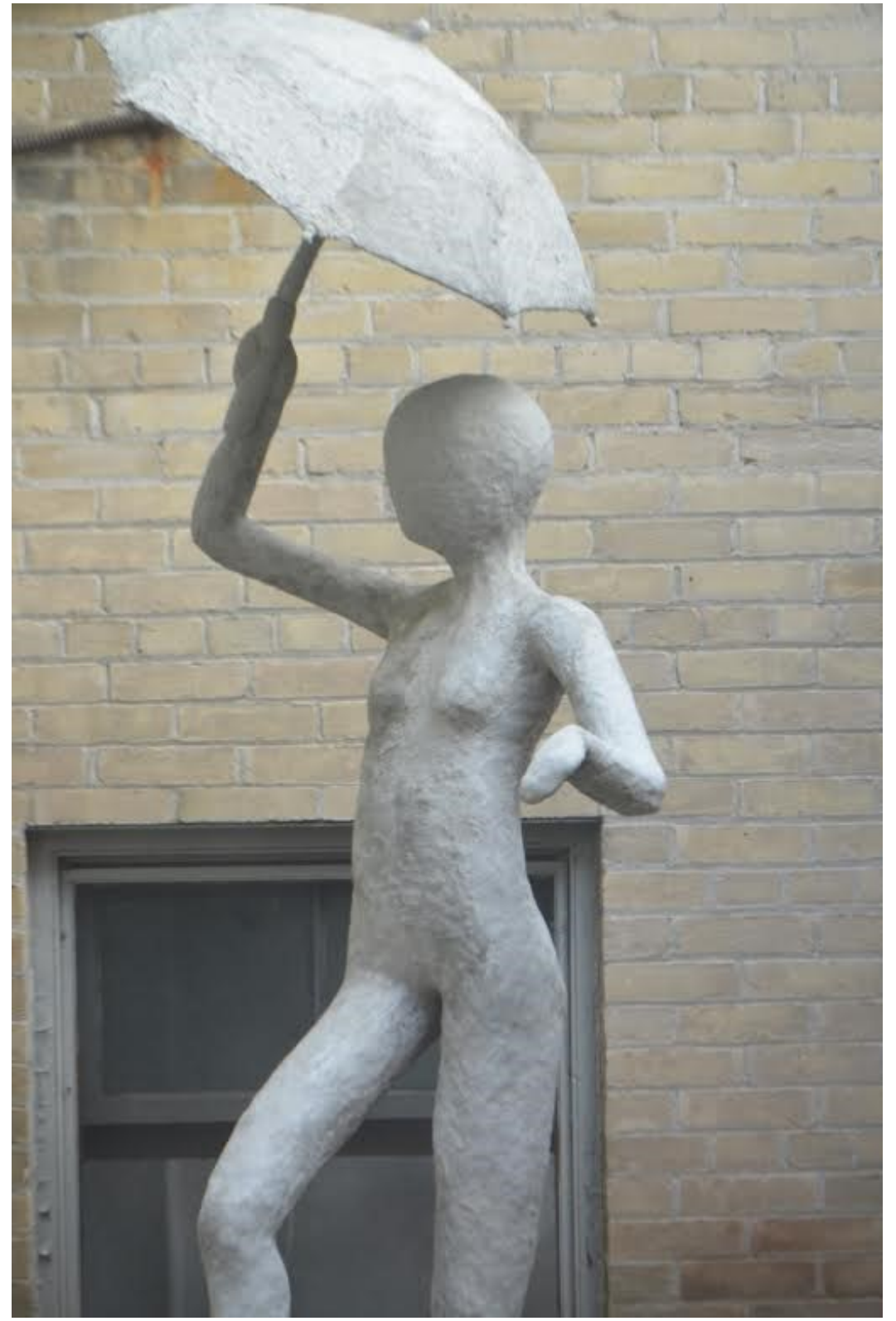

Figure 1. Beth McCubbin, eternal spirit, 2014, concrete installation at the Sisters of Mount St. Joseph, courtesy of the artist. 


\section{Chapter 1: Introduction}

It's a serious issue in the visual art world how language - or writing - has now been squished on to it. It's touchy. I'm not the only person who feels that about writing. I have many visual artists-friends who are the same. There is a bitterness about the arts world, and a lot of it comes from the writing. There is a serious resentment and bitterness. [Visual artists] are forced to have to justify themselves in writing.

In one of a series of interviews that I conducted, visual artist Beth McCubbin described a bitterness in the art world that comes from the way written/spoken language has been "squished on to it." Her understanding shaped how my research progressed. The phrase "squished on to it" obscures the practices and relations involved. It blurs the work of other artists and art professionals. It brushes over the who's who and what's what of squishing and of bringing about bitterness. It also opens up a line of inquiry, points to a field of activity, and hints at an institutional terrain to be discovered. It serves as a critical point of entry from which to begin this institutional ethnography of the art world.

Responding to Beth's concerns, this study examines how visual artists' experiences/knowledges ${ }^{1}$ are coordinated institutionally in and through social relations that extend beyond them. This study investigates critically the conjunction between art and language in the work of artists, in the work of curators and in the institutional art world ${ }^{2}$. While art work typically refers to the material art objects themselves, and sometimes, though to a lesser extent, to the work of producing art, this study calls attention to the coordinated institutional work shaping (and shaped by) artists' and curators' experiences/knowledges. This study examines

\footnotetext{
${ }^{1}$ I use the term 'experiences/knowledges' to signal how doing is a way of knowing.

${ }^{2}$ I use the terms regime, institution, terrain and art world interchangeably to refer to the array of connections and coordinations that make up the art world across sites. I don't use these terms to refer to any one site or any one particular gallery, but rather to the inter-connected text-based work of people across diverse sites, including, galleries, studios, universities and funding bodies.
} 
critically the actual work of artists and curators situated in Ontario while opening up the institutional workings of the larger art world.

\section{The project}

My scholarly interest in the art world, and in the institutionally organized experiences of visual artists, initiated in conversation with Beth, a visual artist that I know and care about. Beth and I have known each other for several years. We met in Peterborough, where she worked as a visual artist and I dabbled in social service and in stand up comedy. Over the years, I enjoyed getting to know Beth, meeting her for dinner with mutual friends, and following her work as an artist. We met in the fall of 2013 on more serious business.

As a part of a class I was taking in workplace writing, I interviewed Beth about the writing she did as a visual artist. As a wordsmith, I confessed to her that I had often read my way through art galleries: reading the blurbs and scribbling down notes. I admitted that I relied on the written texts to mediate my experience in galleries, and that I often did more reading than looking. From there, I asked Beth about writing in the Canadian art world. I started by asking her about the writing on the wall of galleries, the writing that was within my view as an outsider in the world of art. I learned that was just the tip of it.

Beth described the Canadian art world as a text-heavy environment. She talked about writing bio statements, artist statements, CVs, grant applications, and gallery applications. She talked about how writing played a key part in her work as a visual artist. She talked about being evaluated on her writing alone. She said, “it's what the written word says about the work before the work itself." As she put it, "You could just be dismissed because of your writing. It has 
nothing to do with your art." She mentioned that she continually has to justify her art and herself in language.

Taking it further, Beth talked about her struggles with language, and about her struggles to connect up her work to public galleries, to grants and to fancy art speak. She joked that public galleries require her to hold a piece of paper in front of her artwork, blocking the view of the work itself. She mentioned being a "functioning artist" requires a "written component and verbal component," and that she was considering "letting the whole thing go." She said that gallery, grant and travel opportunities go to artists who have been "taught the language tools to go with [their] practice." She attributed her difficulties in the art world to the way language had been "squished on to it."

Standing before her, I felt the weight of her words. If Beth wasn't an artist, I didn't know who was. I felt saddened that her life trajectory was being cut short, and that she was being excluded from grant, gallery and travel opportunities for not having what she called the written and verbal component. I couldn't understand why she was being edged out.

Beth had committed her life to visual art. She had worked as a self-taught practising artist for 25 years. She was well known by locals in Peterborough for her commitment to visual art and her involvement in the downtown art scene. She was well known for turning ceramic, concrete, porcelain and recyclables into works of art, and for recruiting volunteers to help her cart sculptures up and down flights of stairs and across city streets. Her installations had adorned gardens, restaurants, art galleries and alleyways in Peterborough. She had draped a concrete trapeze artist from the roof of a local restaurant, had suspended nearly fifty porcelain birds in a local shop, and had sculpted clay trellises for backyard gardens. Her work was a part of the city, 
and her home was an elaborate studio. At one point, I remember visiting her to see that she was in the middle of making a concrete sculpture of a woman (see Figure 1) between her kitchen sink and kitchen table, to which she explained nonchalantly that it would only be there for a few more weeks. Again, I felt the weight of her words.

Beth's sense of being excluded institutionally was familiar to me. I felt that she was giving voice to something I had experienced. While I am not a visual artist, I too had experienced the alienating effects of the contemporary work world. Listening to her, I called to mind my own work experience. Quite briefly, after several years of working as a front-line worker in the social service sector, where I supported trauma survivors, individuals experiencing homelessness, and individuals with intellectual disabilities, I ended up with a debilitating burn out, with every sign of compassion fatigue, and with a profound sense of resentment for the way I had been spit out by the system. Beth's experience of being edged out connected with me deeply. Initially, this thesis was motivated by my admiration for Beth, by my deep compassion for pain and exclusion, and by my own desire to carve out space institutionally. I started by exploring the work experiences/knowledges of visual artists. As the study progressed, I moved to exploring the work experiences/knowledges of other art professionals, including public gallery curators and art critics. I should say though, that it wasn't until after first interviewing Beth that I was introduced to the language of institutional ethnography as a part of classes I took in adult literacy and institutional ethnography (Darville, 1995, 2009, 2014).

\section{Institutional ethnography}

Developed by Dorothy E. Smith $(2005,2006)$, institutional ethnography (IE) is an analytic method and theorized way of looking at social reality. In IE, the aim is to explicate how local experiences/knowledges are coordinated institutionally. To explicate means to open up, 
map, uncover, tease out, or render visible. IE is about opening up extended social relations, which are a "complex and massive coordinating of people's work" (Smith, 2005, p. 183). Instead of starting with a conceptual puzzle or research gap, IE starts by examining local activities to understand how they come to happen as they do in and through coordinated institutional processes. IE aims to uncover both how institutional relations shape particular activities and how particular activities shape institutions. Campbell and Gregor write, "not understanding an organization is a form of domination" (2002, p. 15). The liberatory promise of IE-to open up institutional relations - was very much in line with my desire to understand Beth's experience. In fact, the way that Beth distinguished between her own experiential ways of knowing and doing, and the language squish that was happening out of view was akin to what institutional ethnographers (e.g., Campbell \& Gregor, 2002; Smith, 1990b, 2005) refer to as a disjuncture. IE came with an invitation to not only commit to knowing on behalf of others, but to discover more about the institutional terrain (of which Beth's experience was a moment). IE allowed me to take visual artists' experiences/knowledges as an entry point into the extended social relations of the institutional art world. It gave me a way of engaging in social research for — not about—people.

\section{Problematic for investigation}

Again, Beth voiced concerns about language being squished on to the art world, about continually having to put art into words, and about the ways her work was being both misrepresented and underrepresented in the art world. Beth's concerns gave me an investigatory focus, directing my exploration beyond her local experience. In institutional ethnography, such a puzzle is viewed as a problematic for investigation. Institutional ethnographers view the problematic not as a question to be answered, but as a territory to be discovered (Smith, 2005, p. 41). The aim is to discover how differing experiences are put together (Campbell \& Gregor, 
2002, p. 17), recognizing that everyday events are "hooked into a larger fabric [that] is not directly observable from within the everyday" (Smith, 2005, p. 39). The focus of my research isn't on artists themselves, but on how artists participate in the institutional art regime. Artists' experiences/knowledges are a starting point from which to investigate the art world, and from which to understand how their work experiences are hooked into the work experiences of others. IE explores how people "are implicated in social organization that extends beyond them" (Campbell \& Gregor, 2002, p. 44). As such, this study explores the work of visual artists, the work of public gallery curators, and the institutional workings of the art world. This study follows a line of discovery that is anchored in and responsive to particular experiences.

The overarching aim of this study is to understand visual artists' and public gallery curators' experiences, to understand how language is a part of them, and to understand how they are institutionally coordinated within the larger art regime. My study asks these questions:

1. What is artists' actual work? How does the conjunction between art and language in artists' work mediate relations in the art regime?

2. What is curators' actual work? How does the conjunction between art and language in curators' work mediate relations in the art regime?

To answer these questions, I entered into dialogue with people situated differently in the art world. I collected data through open-ended interviews, observational field notes, and textual analyses. Working as an institutional ethnographer, I started by investigating artists' activities and moved to investigating curators' activities as a way of opening up the institutional art regime. I aimed to understand how Beth's experience of being squished arose in the art world, 
and was connected to the ways other people and institutions organize activities and reproduce knowledges.

\section{Overview of chapters}

Chapter 1 has been an introduction to the objectives of the research. Chapter 2 will elaborate on institutional ethnography as a theorized way of looking at social reality. Chapter 3 will paint a picture of the Canadian art world, of artists and of artwork. Chapters 4 and 5 are devoted to the analysis. Chapter 4 will highlight visual artists' work and the written/spoken discourse within it. With a view to opening up the art world, Chapter 5 will examine curators' multi-faceted work across sites. Chapter 6 will summarize key findings, offer a reflection, and highlight the invitations and implications that come with the research. 


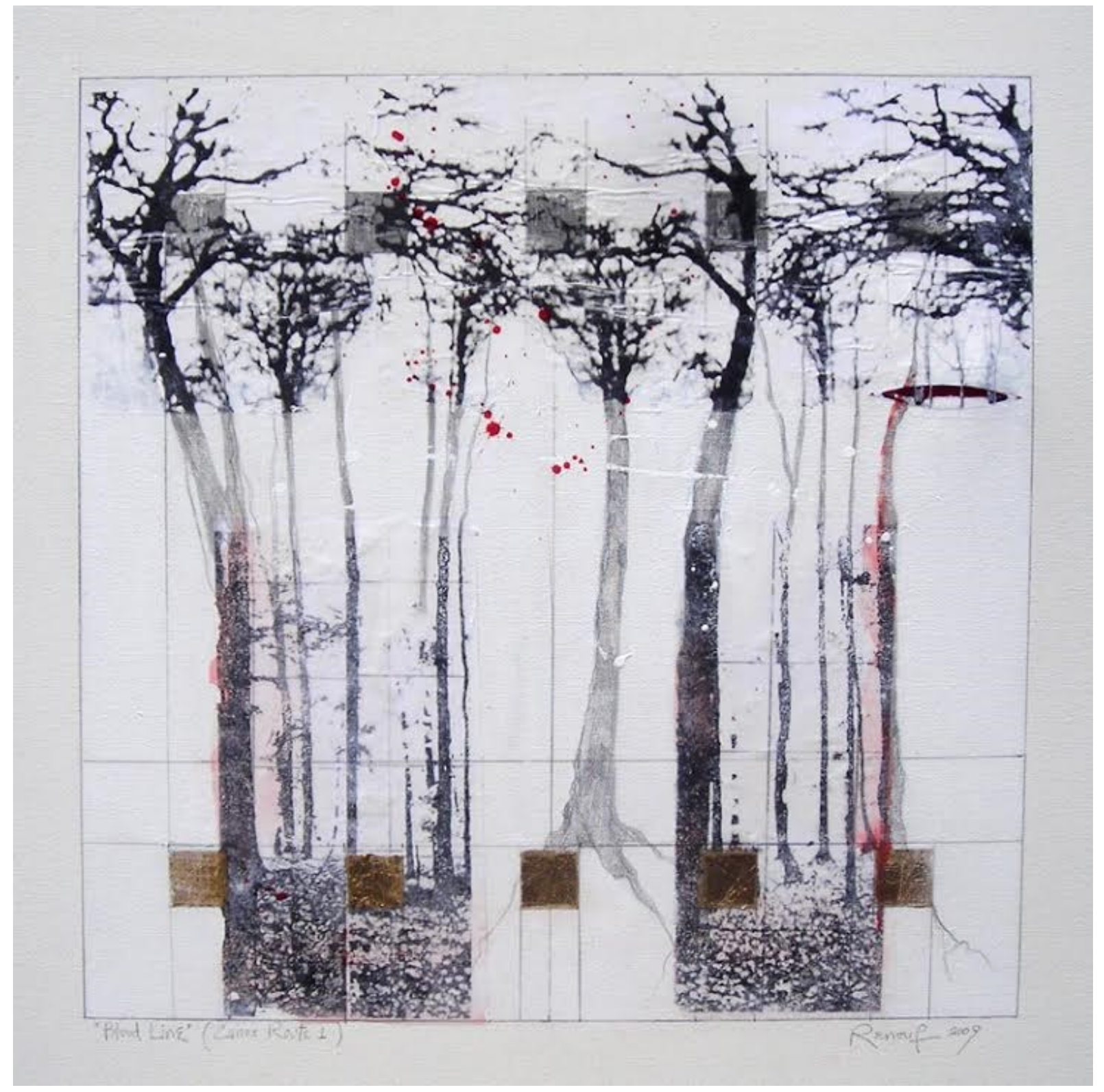

Figure 2. Anne Renouf, Bloodline, 2009, courtesy of the artist. 


\section{Chapter 2: Theory and methods}

\section{Institutional ethnography}

Developed by Smith $(2005,2006)$, institutional ethnography is a method of inquiry and a theorized way of looking at social reality, combining theory and method. As Diamond (2006) puts it, "Institutional ethnography is a materialist method; it searches out the social relations contained within materials and studies the relations as themselves material” (2006, p. 52). IE examines actual practices and relations; actual language in use. IE explores how "the very organization of the everyday is permeated with connections that extend beyond it" (Smith, 2005, p. 40). Devault and McCoy (2002) write:

the research follows a sequence: (a) identify an experience, (b) identify some of the institutional processes that are shaping that experience, and (c) investigate those processes in order to describe analytically how they operate as the grounds of the experience. (p. 755)

My own study follows this sequence-beginning with visual artists' experiences and tracing out how those experiences are coordinated in and through institutional processes. This chapter will unpack IE as a theory and a method. First, though, I will briefly situate my own study in the discipline.

Recent institutional ethnographies have examined critically how work is coordinated in organizations, and how much of that work is coordinated through the medium of texts. By and large, these studies have investigated work in the public sector; particularly in health (Rankin \& Campbell, 2006; Rankin \& Tate, 2014; Sinding, 2014), education (Darville, 2014; Kerr, 2014; McCoy, 1998; Wright, 2014), social services (Janz, 2014; McCoy, 2014; Nichols, 2014), and international development (Campbell, 2014; Eastwood, 2005). Starting in actual places where people work and do things together, these studies have kept people and texts in view while 
investigating coordinated work that is (sometimes) out of view. These studies have made known how textual technologies (and managerial re-organizing initiatives) translate the actualities of people's real work into standardized, measurable and managerial forms (see Griffith \& Smith, 2014). Entering into the field, I wasn't initially sure how the art world - replete with fancy art speak and a so-called language squish — fit in with studies about medical charts, standardized reports, educational policies and behavioural tracking charts. I wasn't sure how - or whether or not-visual artists' experiences were connected to other institutional practices and relations. That said, Beth McCubbin indeed pointed to a problematic for investigation and to a text-based terrain of inquiry. Her own sense of a disjuncture between her work on the ground and the way language was being squished on to the art world helped to direct my inquiry into how visual artists' experiences are permeated with and put together by extended, coordinated practices and relations.

\section{A theorized way of looking}

IE begins inquiry from the standpoint of some(one's) particular experience. A standpoint refers not to inner psychological experience or to thoughts or feelings, but to "material," practices and relations, anchored in reality. It refers to events people live through in their work and in their relations(hips) with others. A standpoint is a local, particular, and embodied subject position (Diamond, 2006, p. 48) in that it involves real activities and knowledges. In my project, I was interested in how visual artists, some of whom I knew and cared about, participated in the contemporary art world. I saw them as embodied knowers and expert practitioners telling me what they know about their individual and institutional experiences.

IE recognizes that particular experiences - what people live through in their work and relationships - are not stand-alone, but rather involve, depend upon, aim at, are hooked together 
with other events and circumstances both near and far-flung. As Smith (2005) writes, "any one individual's story necessarily implies the presence of others caught up in and participating in relations that coordinate their doings" (p. 43). Experience isn't a theoretical object to be viewed, but an opening to how people participate in actual institutional processes formally and informally. Particular experiences/knowledges are always coordinated with other particular experiences/knowledges across sites (Smith, 2006, p. 59).

To focus on this coordinating of work experience, IE uses the notion of institution to refer to the ways that major social functions in society are accomplished, organized and coordinated across diverse sites of activity. An institution is comprised of the "ongoing concerting of activities" (Diamond, 2006, p. 60). This concerting of activities in diverse sites across space and time is mediated by texts whose use in one setting sutures activity there into activity in other settings. An institution is active and activated — not stabilized in individual psyches or collective structures - but produced in and through practices and relations. The art world, a major social/professional sphere, is very much coordinated in and through the ordinary (text-based) work of real people across "discursive sites" (Smith, 1999, p. 59).

The aim is to open up how experience is coordinated by institutional relations that extend beyond it. In IE, particular experiences are an "entry-point" into institutions. We can begin to understand how a major social function is coordinated by beginning with a focus on experience that is one of its moments. In IE, the concept of standpoint serves as a "methodological device" (Smith, 2005, p. 206) in that it can be used as a point of inquiry into the social world. The experiential starting-point is said to open up a problematic - the terrain that requires investigation and explication in order to discover how the experience in question comes to happen as it does. 
Two key ideas in IE help to direct this inquiry and to open up the art world. First, what have here been called experiences, knowledges, and coordinated work across sites are conceived as social relations. In IE, social relations are connections and coordinations among people who are not necessarily in face-to-face contact or personally known to one another. Social relations are, of course, ordinarily "institutional." Second, in IE, the coordination of these social relations depends on language and texts. Texts, which have a graphic, visual and/or auditory character (Nichols, 2011, p. 30), refer to situated material objects that are deployed within particular sequences of action. Institutional relations are textually mediated. Texts organize and mediate action. This mediation happens as texts/documents move across various discursive sites, and as they are used within the work of actual people at particular times and places (Smith \& Turner, 2014, p. 306). Devault (2008) writes, "Institutional ethnographers attend closely to the production and uses of texts and to the ways that texts (and the concepts and discourses they contain and reproduce) travel—both literally and figuratively from one setting to another" (p. 4). The kinds of texts, and the kinds of relations texts mediate, are quite various depending on the terrain in question.

Committed to the actual rather than the conceptual, IE inquiries begin with a distinctive ontology of the social. In IE, the social exists in individuals' activities as they are concerted with the activities of other individuals. IE views the social as an object of inquiry (Smith, 2005, p. 69), organized and already orderly. Quoting Smith (1990c) again:

The practice of sociology in which we were trained as graduate students was one that insisted that the sociologist should never go without a concept; that to encounter the raw world was to encounter a world of irremediable disorder and confusion; to even begin to speak sociologically of that world required a concept, or concepts, to order, select, assemble, a sociological version of the world on paper. (p. 2) 
While Smith refers here to research in sociology, her insight connects with social science research more broadly. In IE, the researcher goes in without a concept, aiming to explicate the orderliness that's already there in activity, to discover and explicate it. This, again, is what makes IE distinctive and even radical vis-à-vis many other forms of social science, which start from or aim at theoretical formulation, as if a disorderly messy world needs to be approached and categorized with concepts. In IE, the world itself is recognized as orderly. As Schegloff and Sacks (1973) write, specifically about features of conversational organization, "in so far as the materials we worked with exhibited orderliness, they did so not only to us, indeed not in the first place for us, but for the co-participants who had produced them" (p. 290). Co-participants produce order and orderliness. Put another way, materials exhibit orderliness first and foremost for the co-participants who produce them. Written and spoken utterances are taken up in this thesis not to contribute to a particular theoretical workup, but instead as constituents of coordinated activity in the art world.

\section{Research process}

In IE, the aim is to explicate how local experiences are coordinated institutionally. As Smith describes, "Investigation does not, of course, stop at the level of experience, but experience opens up a line of investigation" (1990a, p. 11). In this study, visual artists' experiences/knowledges are an entry point into the social relations of the art world. In speaking of the research process, Campbell (2006) writes:

Institutional ethnography, like other forms of ethnography, relies on interviewing, observation, and documents as data. Institutional ethnography departs from other ethnographic approaches by treating those data not as the topic or the point of interest, but as "entry" into the social relations of the setting. The idea is to tap into people's expertise in the conduct of their everyday lives... (p. 92) 
People's experience isn't a topic or point of interest in itself, but a way of entering into and exploring connections that extend beyond it. Interviewing, observation and documents are data that provide displays of social relations. This project relies on semi-structured interviews, observational field notes and textual analysis for data. This project includes data collected from 20 semi-structured interviews with 16 people working in Ontario's art world, including, nine practicing visual artists, four gallery curators, and one art critic. I made observational field notes at numerous gallery visits, several art events, and two studio visits. I also analysed key institutional texts, including, artist statements, bio statements, online portfolios, CVs, organizational mandates, popular publications, and exhibition promotional materials. This analysis is based on the interviews, field notes and textual analyses and on a dialogical rethinking and reworking of the materials.

\section{Researcher standpoint}

"When I see a writer, a word [wo]man, among a number of painters, I shake my head. For I know that [s] he would not be there unless [s] he was up to something. " - Wyndham Lewis (1954).

As a researcher, I was, of course, part of the dialogue. I was actively involved in the production of the accounts featured in this thesis. I didn't observe the art world from afar-nor did I study it in isolation from my very self. In IE, the researcher's own bias isn't a problem to be overcome, but a part of the process. As Smith (1990c) puts it:

Knowing is always a relation between knower and known. The knower cannot be collapsed into the known, cannot be eliminated; the knower's presence is always presupposed. To know is always to know on some terms, and the paradox of knowing is that we discover in its object the lineaments of what we already know. (p. 33)

Indeed the knower's presence is presupposed in this project. Just as Bakhtin (1986) views knowledge as inherently dialogical — made in relation to others — this thesis was made in relation between myself and others. As a researcher, I didn't obtain knowledge by standing outside the 
art world, but by engaging directly. As such, it is important that I share about myself. I mentioned in Chapter 1 that Beth McCubbin's sense of being excluded institutionally was familiar to me, and that this project was very much an effort to - not only make sense of her experience — but to understand my own own institutional experiences. I was motivated to understand how people are set up institutionally. I viewed the "professional self [as] a fractured self" (de Montigny, 1995a, p. 14). I was deeply critical of the ways institutions exclude, and had often glossed over my own work experience (including my debilitating burn out) as a "brush with the institution" and a "chafe against the system." I was drawn in by the liberatory promise of IE, the promise of understanding what I had marked as "institutional domination." I entered into this project with a desire to make change from below.

As a researcher, I found myself admiring artists who were true to themselves without being bitter about the price they had to pay for it. I found myself rolling my eyes at the out-ofoffice emails from curators, who were very-much positioned differently from some artists working around the clock. I found myself comparing (or was it begrudging?) the sizable number of professionals on the payroll at public galleries with the very few working artists being supported. I found myself keeping score, cheering for the underdog, and letting my own critiques slip out in conversation with others. My own institutional experiences inevitably shaped how the research progressed.

That said, working as an institutional ethnographer meant reining myself in, suspending my desire to turn subjective experiences into quick-fire rants, and attending to experience differently. This project meant engaging as an analytical mapmaker-mapping institutional happenings — instead of as a comedian — poking fun at the system and giving voice to the subjective experiences of myself and others. Doing IE meant slowing down, digging deeper and 
examining how particular experiences were discursively and institutionally coordinated. My mandate wasn't to recount subjective personal accounts, but to trace out connections, and explore how experiences/knowledges are institutionally coordinated in and through practices and relations that extend beyond them. Doing IE meant finding new ways of coming to know, and of paying attention to extended social relations (of which I am a part). And, this process - in which “no one story overrides; no story is suppressed" (Smith, 2005, p. 143)— was difficult, demanding and, in the end, surprising. 


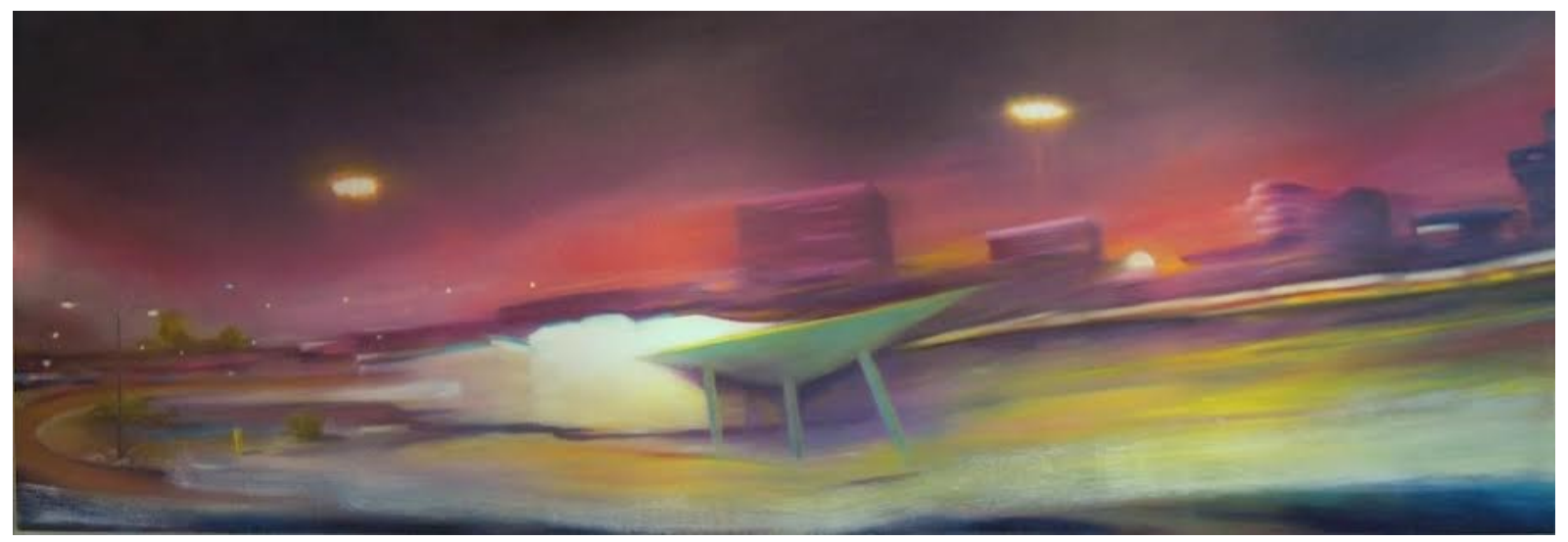

Figure 3. Petra Halkes. Strip, 2011, 3.5 feet by 10 feet, courtesy of the artist. 


\section{Chapter 3: Going in without a concept}

When it came to explicating the art world, I didn't go in with "a concept, or concepts, to order, select, assemble, a sociological version of the world on paper" (Smith, 1990c, p. 2). While I, of course, did use IE as a theorized way of looking, and did draw on and aim to explicate the conceptual understandings of art world participants, I didn't use a particular conceptual framework to regulate how data would be interpreted or to selectively represent/displace people or people's activities (Smith, 2005, p. 31). Instead, I worked from people's experiences (Smith, 2005 , p. 44), inquiring and discovering. The aim of this study is to know the social— to "begin in the actualities of the lives of some of those involved in the institutional process and focus on how those actualities [are] embedded in social relations" (Smith, 2005, p. 31). The aim of this study is to investigate actual language in use, actual practices and relations.

As a part of my investigation, I approached the art world as a domain shaped by people participating in ordinary discursive and institutional practices and relations. I viewed the art world, a major social/professional sphere, as coordinated in and through the ordinary (text mediated) work of real people across "discursive sites" (Smith, 1999, p. 59). I recognized that the art world — the terrain where art is produced materially/discursively—involves an array of connections, discourses, practices and relations. Figure 4 highlights some of the interconnected, coordinated work in the institutional art world. While there are, of course, countless ways of entering into the art world, I started my investigation by interviewing practising visual artists about their work in the regime. 


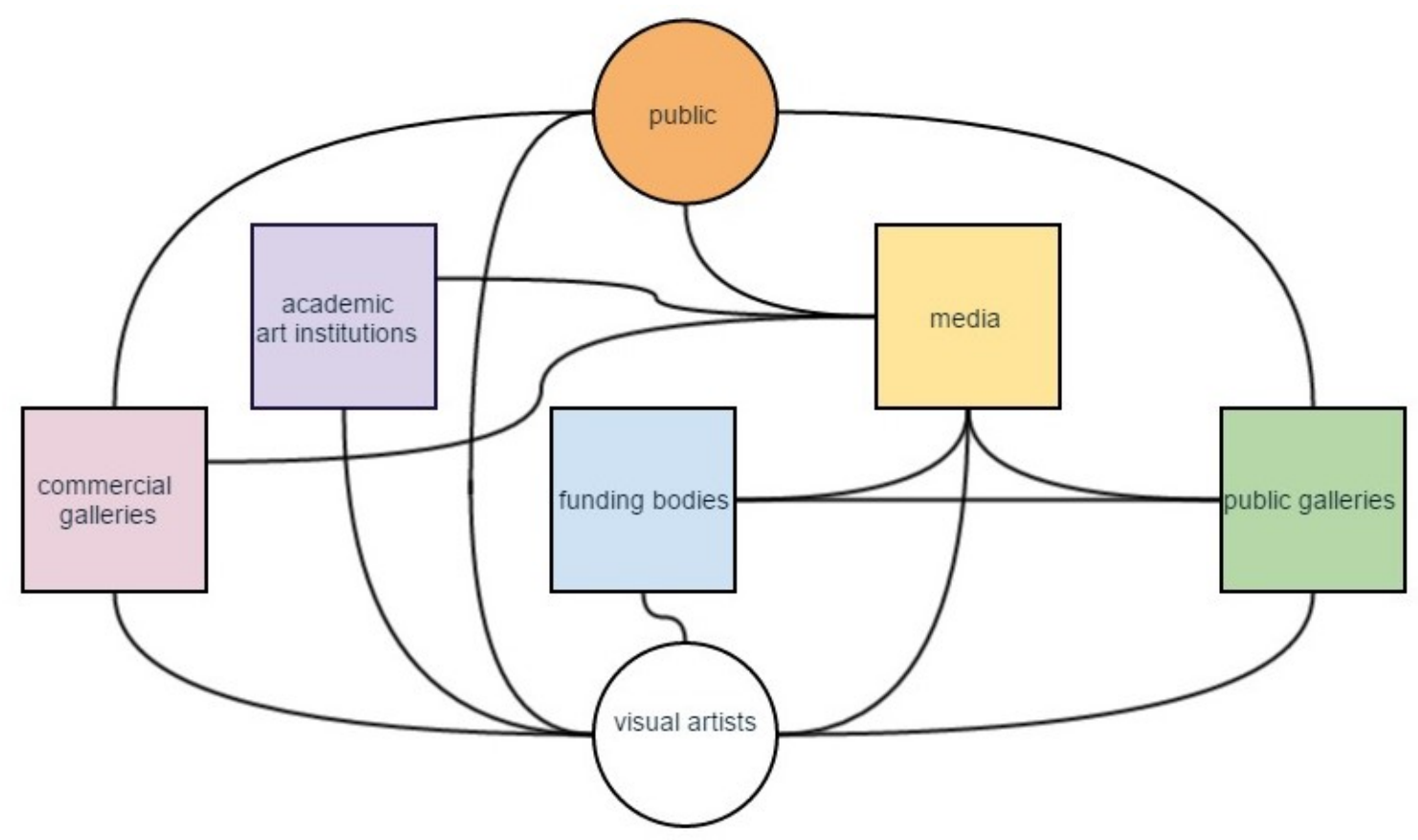

Figure 4. Coordinated art work

Before introducing the people I interviewed and the documents that played a part in my analysis of the institutional terrain, I want to mention that this research was approved by Carleton University’s Research Ethics Board (see Appendix A for Ethics Clearance Form). All data was collected between September 2014 and April of 2015. As per best practices, participants received information about the study and the purpose of the study prior to the interviews. This information included both formal invitation letters and consent forms (that explained their options for remaining anonymous or being identified). I should also mention-since it is unconventional— that all participants included in this thesis opted both verbally and in writing to be identified by their real names, and to have their responses and data attributed to them (see Appendix B for Consent Form). Their work and their words are attributed to them accordingly. Interviews typically lasted an hour, and focused on the work and workplace writing participants do. While I 
initially focused on people's writing practices, participants drew my attention to the importance of both written and spoken discourse. While the majority of interviews were conducted in-person at locations selected by participants, some were conducted on the phone for convenience. With permission, I audio-recorded and transcribed all interviews. In transcribing, some quotations were edited to remove hesitations or false starts. In a few cases, I disguised participants' names when their statements could be interpreted as critical of others or could carry professional or economic risks. As a part of the process, some participants also opted to review their transcribed materials, which added another layer of consent. Participants also graciously submitted digitized reproductions of their artwork and samples of their writing to include in the project.

\section{Participants}

As a part of the project, I interviewed 16 people working in Ontario's art world, including nine practicing visual artists and five art professionals (e.g., public gallery curators and critics). The practising artists that I interviewed resided in the communities of Gatineau, Hamilton, Kingston, Ottawa, Peterborough and Toronto. I interviewed women artists. While gender wasn't at the forefront of my analytical interest, I chose to study the experiences of women artists, because of my personal interest in learning about other women's experiences in light of my own. Starting from the standpoint of women artists was also an important personal choice as the marginalization of women in art has been well documented both in contemporary and historical contexts (Bain, 2004; Dimitrakaki, 2013; Eimen, 2006; Nochlin, 1971; Sefton, 2006).

As a part of my inquiry, I also interviewed five art professionals: four public gallery curators and one art critic. It is worth noting that artist Petra Halkes is also an independent curator and an art critic, but that I interviewed her mainly about her work as an artist. The art professionals I interviewed worked in Ottawa, Peterborough and Toronto. 
Table 1 includes brief bios of the participants I interviewed. I should make explicit that the bios that follow highlight participants' institutional affiliations. Bio shaping is very much a political and conceptual practice. To write the bios, I gathered information about participants' cities, educational backgrounds and work experiences. These biographical accounts tell it slant, bracketing much of participants' real experiences/knowledges, which will be explored in Chapters 4 and 5 .

Table 1

Participants' biographies

\begin{tabular}{|c|c|c|c|}
\hline Name & City & Education & Experience \\
\hline $\begin{array}{l}\text { Heather } \\
\text { Anderson }\end{array}$ & Ottawa, ON & $\begin{array}{l}\text { She holds a Master's (MA) in } \\
\text { Women's Studies from Dalhousie } \\
\text { University (2003), a Bachelor of } \\
\text { Fine Arts (BFA) from Emily Carr } \\
\text { University of Art and Design } \\
\text { (1998), and a Diploma in Fine } \\
\text { Arts from Langara College } \\
\text { (1995). }\end{array}$ & $\begin{array}{l}\text { She is the curator at the } \\
\text { Carleton University Art } \\
\text { Gallery (Ottawa, ON). }\end{array}$ \\
\hline $\begin{array}{l}\text { Andrea } \\
\text { Campbell }\end{array}$ & Ottawa, ON & $\begin{array}{l}\text { She holds a Master of Fine Arts } \\
\text { (MFA) from the University of } \\
\text { Ottawa (2013), and a BFA from } \\
\text { NSCAD University (2007). }\end{array}$ & $\begin{array}{l}\text { She uses photography and } \\
\text { archival practices in her work. }\end{array}$ \\
\hline $\begin{array}{l}\text { Sky } \\
\text { Goodden }\end{array}$ & Toronto, ON & $\begin{array}{l}\text { She holds an MFA in Criticism } \\
\text { and Curatorial Practice from } \\
\text { OCAD University (2010). }\end{array}$ & $\begin{array}{l}\text { She is an art critic, and } \\
\text { founding editor of } M O M U S \text {, an } \\
\text { international art publication. }\end{array}$ \\
\hline $\begin{array}{l}\text { Petra } \\
\text { Halkes }\end{array}$ & Ottawa, ON & $\begin{array}{l}\text { She holds a PhD from The } \\
\text { Amsterdam School of Cultural } \\
\text { Analysis (2001), an MA in } \\
\text { Canadian Art History from } \\
\text { Carleton University (1995), and a } \\
\text { BFA from the University of } \\
\text { Ottawa (1989). }\end{array}$ & $\begin{array}{l}\text { She has been a practising artist } \\
\text { for over } 25 \text { years. She is a } \\
\text { painter, independent curator } \\
\text { and art writer. }\end{array}$ \\
\hline $\begin{array}{l}\text { Marika } \\
\text { Jemma }\end{array}$ & Ottawa, ON & $\begin{array}{l}\text { She graduated from art school in } \\
1991 .\end{array}$ & $\begin{array}{l}\text { She has been a visual artist for } \\
\text { more than } 20 \text { years. She works } \\
\text { "primarily in the mediums of } \\
\text { sculptural installation and } \\
\text { video, combining natural and } \\
\text { manufactured objects." }\end{array}$ \\
\hline
\end{tabular}




\begin{tabular}{|c|c|c|c|}
\hline $\begin{array}{l}\text { Sharon } \\
\text { Katz }\end{array}$ & Ottawa, ON & $\begin{array}{l}\text { She holds an MFA from the } \\
\text { University of Ottawa (2014). }\end{array}$ & $\begin{array}{l}\text { She has been a visual artist } \\
\text { since } 1983 \text {. She works in the } \\
\text { mediums of drawing and } \\
\text { animation/video. }\end{array}$ \\
\hline $\begin{array}{l}\text { Fynn } \\
\text { Leitch }\end{array}$ & $\begin{array}{l}\text { Peterborough, } \\
\text { ON }\end{array}$ & $\begin{array}{l}\text { She received an MA in Visual } \\
\text { Culture from Queen's University } \\
\text { (2006). }\end{array}$ & $\begin{array}{l}\text { She is the curator at the Art } \\
\text { Gallery of Peterborough }(\mathrm{ON}) \text {. }\end{array}$ \\
\hline $\begin{array}{l}\text { Virginia } \\
\text { Marie }\end{array}$ & $\begin{array}{l}\text { Hamilton, } \\
\text { ON }\end{array}$ & $\begin{array}{l}\text { She received what she called } \\
\text { "non-academic" and "all hands- } \\
\text { on, paint, sculpt, do your thing" } \\
\text { training at the Saidye Bronfman } \\
\text { Centre. }\end{array}$ & $\begin{array}{l}\text { She has been painting full-time } \\
\text { for } 15 \text { years. She works in the } \\
\text { medium of "oil on anything." }\end{array}$ \\
\hline $\begin{array}{l}\text { Beth } \\
\text { McCubbin }\end{array}$ & Gatineau, GC & She is a self-taught artist. & $\begin{array}{l}\text { She has been working in the } \\
\text { arts for } 25 \text { years. She is an } \\
\text { artist and conservator. She } \\
\text { works primarily with clay, } \\
\text { concrete and other mixed } \\
\text { materials. }\end{array}$ \\
\hline $\begin{array}{l}\text { Mary } \\
\text { Porter }\end{array}$ & Toronto, ON & $\begin{array}{l}\text { She holds an MFA from York } \\
\text { University (2008), a Bachelor of } \\
\text { Education from the University of } \\
\text { Toronto, and a BFA from } \\
\text { NSCAD. }\end{array}$ & $\begin{array}{l}\text { She works in the mediums of } \\
\text { painting, drawing and photo- } \\
\text { based stop-motion animation. } \\
\text { She is an instructor at OCAD } \\
\text { University. }\end{array}$ \\
\hline $\begin{array}{l}\text { Anne } \\
\text { Renouf }\end{array}$ & $\begin{array}{l}\text { Peterborough, } \\
\text { ON }\end{array}$ & $\begin{array}{l}\text { She studied fine art at the } \\
\text { University of Toronto. }\end{array}$ & $\begin{array}{l}\text { She works primarily in mixed } \\
\text { medium on canvas. }\end{array}$ \\
\hline $\begin{array}{l}\text { Catherine } \\
\text { Sinclair }\end{array}$ & $\begin{array}{l}\text { Wakefield, } \\
\text { QC }\end{array}$ & $\begin{array}{l}\text { She holds an MA in Canadian Art } \\
\text { History from Carleton University } \\
\text { (2006). }\end{array}$ & $\begin{array}{l}\text { She is the senior curator at the } \\
\text { Ottawa Art Gallery. }\end{array}$ \\
\hline $\begin{array}{l}\text { Jason St- } \\
\text { Laurent }\end{array}$ & Ottawa, ON & $\begin{array}{l}\text { He studied fine arts at the } \\
\text { Université de Moncton and the } \\
\text { University of Toronto. }\end{array}$ & $\begin{array}{l}\text { He is the curator at SAW } \\
\text { Gallery (Ottawa, ON). }\end{array}$ \\
\hline Jinny Yu & Ottawa, ON & $\begin{array}{l}\text { She holds an MFA from York } \\
\text { University (2002), an MBA from } \\
\text { Schulich School of Business } \\
\text { (2002), and a BFA from } \\
\text { Concordia University (1998). }\end{array}$ & $\begin{array}{l}\text { She has been showing } \\
\text { professionally for over twenty } \\
\text { years. She works primarily in } \\
\text { experimental painting. She is a } \\
\text { professor at the University of } \\
\text { Ottawa. }\end{array}$ \\
\hline
\end{tabular}




\section{Artwork}

Visual artwork traditionally refers to the production of art and to works of art themselves (e.g., paintings, drawings, photographs). Art is a cultural phenomenon, a tangible artistic product/object, and, for many, a form of knowledge. With the permission of participants, I have included visual reproductions of their artwork in this text. Representing artists without their art is a strange distortion (Sefton, 2006, p. 300). My hope is that including digitized reproductions of artists' work will help to centre them in the text (Sefton, 2006, p. 19), and invite their work to be 'read' alongside, and in conjunction with, their words. In including images of their work, I hope to offer a visual presence of them. While this thesis is very much concerned with words about art, my focus isn't on explicating or interpreting the works themselves. I have not included any interpretations alongside the images. This is a deliberate choice given that I am an outsider in the art world (without any training in reading an art object), and given that some of the artists I interviewed resented some interpretations of their work.

\section{Written texts}

As I learned from artists and curators, I came to see that reading, interpreting and producing written texts is a key part of their work. The art world is a highly textualized environment. Written texts play a key role in the work of artists and in the work of art professionals. Artists write artist statements, bio statements, CVs, portfolios, grant applications and funding applications. As Virginia Marie pointed out, she couldn't even attend a remote artist residency without having to write. Alongside an endless slew of emails, curators talked about writing exhibition promotion materials (e.g., introductory texts, brochures, and "didactic panels" a.k.a. writing on the wall), funding applications, exhibition catalogues, critical essays and reviews. Written texts play a key role in my analysis. 


\section{Past (Canadian) art studies}

Past studies have used an ethnographic approach to investigate Canada's art world. The works of Bain (2004), Rusted (2006) and Sefton (2006) are of particular interest to my inquiry as they examine some of the ordinary, behind-the-scenes practices and relations involved in bringing about the art world.

In her work, Bain (2004) shed light on the work demands and "different activities quite unrelated to the production of art" (p. 188) that women artists, who are partners and mothers, engage in. Narrowing in on the "varied demands of domesticity" (p. 186), her analysis made known the material realities of being an artist.

Rusted's (2006) institutional ethnography traced his experience curating a cowboy art show. As a part of his inquiry, he shed light on how institutional policies organize the ways that artwork is collected, legitimated and exhibited. Tracing behind-the-scenes everyday practices and relations, Rusted positioned curating as a textual enterprise that not only represents and explicates visual art, but also works to activate and assign ruling concepts. Rusted made known how textual practices - that blur the real behind-the-scenes work involved - produce the legitimacy of the art institution (p. 121) while diminishing the complex and embodied world of production.

Sefton's (2006) research examined the role of graduate education in shaping the development of professional artists. She considered how the institutional practices, including textual, aesthetic and theoretical practices, of MFA programs have implications for the professional identities of artists. Tracing the actual text-based work involved, Sefton positioned becoming an artist as an "ongoing project of personal transformation and intellectual 
engagement” (p. 281). Further, she positioned MFA programs as a way for artists to gain legitimacy in the professionalized art world — acquiring knowledge about theoretical and critical discourse and about producing artwork within the context of theoretical and critical discourse (p. 277).

These contemporary ethnographies didn't start in the upper echelon of the art worldmingling at the Venice Biennial or interviewing celebrity artists. Instead, they investigated the local, situated work of practicing artists and art professionals. Similarly, my own inquiry examines critically the local Canadian art world as a site for social action. That said, while these studies have helped fuel my own inquiry, my research turns in a slightly different direction. Again, the overarching aim of this study is to understand how written and spoken language is a part of artists' and curators' work to participate in the institutional art regime. 


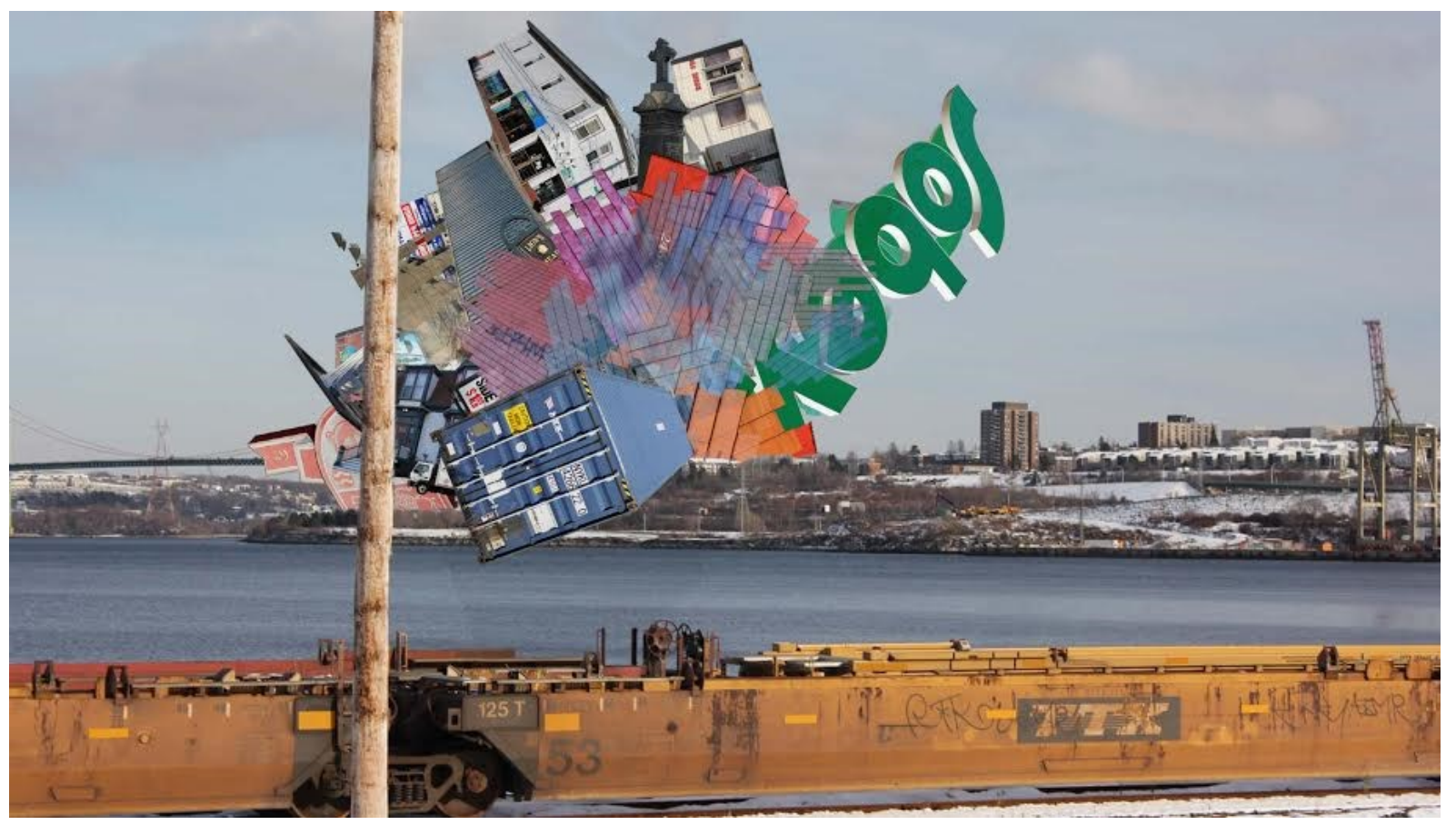

Figure 5. Mary Porter, film still from North End, 2014, digital photo collage animation, courtesy of the artist. 


\section{Chapter 4: Artists' coordinated (language) work}

"Art is odd, and the common method of trying to fit it into the scheme of things, either by taming it or baiting it, cannot succeed. Who at the zoo has any sense of a lion?" - Jeanette Winterson (1995, p. 5)

To understand the art world, it is important to understand artists' work, and the written and spoken language that is a part of it. In one of my first interviews, I asked Mary Porter about what she has to do to be an artist. She said:

I try to make sure I'm pursuing the kind of opportunities that allow you to authenticate or show markers of being a professional artist. Exhibiting is obviously a huge thing, and applying for grants so that you have some sort of funding outside and you can make space for making work. Having enough time to make work to present it is pretty crucial. There is that external validation aspect of knowing that your work is engaged in and validated by other professionals - other people who are engaged in the conversationand who are sort of seeing that there is something relevant about your work.

Of course what Mary knows and says about an artist's work conveys what she does - her material practices and her practical engagement in the social relations of the art world. In her account, she gives expression to a field of activity, opening up to analysis the regime that her work and her experience are parts of. She expresses a variety of social relations, which she glosses as "opportunities." She specifically mentions having exhibitions and applying for grants. Such opportunities allow one "to authenticate ... being a professional artist." They provide "external validation" from "other people who are engaged in the conversation — and who are ... seeing that there is something relevant about your work." Although it is not explicit in what she says, language and concepts are central, not only in "pursuing opportunities" and in "validation in the conversation," but even in the studio itself, in the processes of art-making. Much of artists' work to coordinate within and beyond the studio involves language and texts. To summarize, most artists described doing some if not all of the following work (Table 2). 
Table 2

Artists' coordinated work

\begin{tabular}{|c|c|}
\hline Make artwork & $\begin{array}{l}\text { producing art objects; developing practice; maintaining studio; taking an } \\
\text { expressivist or conceptual approach to art-making; working with ideas; } \\
\text { working with intuition }\end{array}$ \\
\hline \multirow[t]{6}{*}{ Get out there } & $\begin{array}{l}\text { producing various written texts (e.g., artist statements, bio statements, CVs, } \\
\text { grant applications, gallery applications, artist talks, online portfolios) }\end{array}$ \\
\hline & $\begin{array}{l}\text { taking part in the "art scene" - hosting studio visits, attending local arts } \\
\text { events, liaising with artists and art professionals, framing/situating practice, } \\
\text { contextualizing/conceptualizing work; receiving media attention; being } \\
\text { critically reviewed in popular publications }\end{array}$ \\
\hline & $\begin{array}{l}\text { applying for/securing opportunities - applying for/showing in exhibitions } \\
\text { (e.g., public and commercial galleries); applying for/attending artist } \\
\text { residencies; applying for/securing funding (e.g., Ontario Arts Council, } \\
\text { Canada Council for the Arts, municipal/regional sources) }\end{array}$ \\
\hline & selling work - from home or vis-à-vis a commercial gallery \\
\hline & $\begin{array}{l}\text { attending art school -receiving studio/material training; receiving } \\
\text { language/conceptual training (vis-à-vis BFA, MFA or PhD programs) }\end{array}$ \\
\hline & $\begin{array}{l}\text { following and staying up to date on art scene - knowing "who's who," } \\
\text { attending local arts events, following the work of others, reading/researching } \\
\text { about contemporary art }\end{array}$ \\
\hline Sustain practice & having material resources (e.g., money, time, space) \\
\hline
\end{tabular}

This chapter attends to the (language) work that artists actually do, and to how they use language to suture themselves into the social relations of the art world. It is worth noting that, sandwiched in the midst of her remarks about opportunities and validation, Mary identifies important "material" resources for art-making: money ("funding"), and "space for making work," and "time to make work." "Validation" of an artist's work, and the material resources necessary for it (money, space and time) are interdependent. This chapter returns, at the end, to look again at these material resources. But to begin, let me turn to art and to art-making, and the place of language and concepts in that. I will trace out the regime from there. 


\section{Making art}

Whether their art-making involves working with natural materials, creating animated works on computer or standing in front of a blank canvas with a paintbrush in hand, the artists I interviewed had various ways of talking about their work. Language appears in and around the detailed work of making the objects in different ways. Artists use language in their art-making process when they distinguish ultramarine blue from cobalt blue, or when they put out a call for people to donate used cellphones for an upcoming installation. There is sometimes talk in the studio itself, and sometimes this is technical or conceptual. Another artist or a friend may visit the studio, and the artist says something about "what I was trying to do here," with reference to some technical issue (brush strokes, colour juxtapositions, whatever), or more conceptually, visà-vis "the idea I'm trying to convey." Mary Porter said, "Oftentimes people can come into your studio and see things in the way that a friend can sort of see something in yourself that you don't always see clearly, but it's there, but not always something you're aware of." For example, Virginia Marie talked about her friend visiting her studio. She said, "Other people can look at my work, like my friend Doug, and say, 'I think there's always that tension between things that move and things that are really solid,' and I found that really interesting." Artists sometimes share about their work while they are in the middle of making it, relying on the feedback of visitors.

Interestingly, some artists saw their art as, so to speak, arising from within or speaking for itself, while others aligned their work with concepts. Some artists described working beyond or below words, while others worked in relation to words or in relation to a "conversation" (as Mary mentioned). One way of putting it would be to say that some artists took an expressivist approach, expressing their inner psyche and personal versions of reality (Volosinov, 1986) while 
others took a conceptual approach, aligning their work with concepts and with the conversation in the arts community.

Regarding intuition and inspiration in art-making, for example, Petra Halkes talked about working with intuition that is "beyond or below words." She said her art escapes words:

You work so much by intuition, and there's something there that is beyond or below words. There's just something more purely intuitive or visual, you know? ... Maybe it's because you're really exploring something in a visual way - in an intuitive way-if you try to put words to it too early it becomes a little-well, then you think, "Why should I do it? I know what this is about." It's more like you're working with some unknown that you'd like to explore, you know? I do believe in visual art there's something that is beyond words. [That] isn't really expressed well in words. I'm not saying that we shouldn't try or that pictures should speak for themselves, because I don't mean that. Some of it just escapes words, because it's a visual thing.

Petra describes her art-making process as working with "intuition," and "exploring something in a visual way." Similarly, Beth McCubbin mentioned, "I try very hard to represent all those pieces in some way visually, so that it doesn't have to require written or spoken language to go with it other than maybe just a title." Speaking of her art-making process, Marika Jemma stated, "there's something in me that drives me to do it." Along the same lines, Virginia Marie said that her inspiration "comes from deep within." As Virginia put it, "I have no control over my inspiration, so I can go to Newfoundland, and come home, and I may or may not paint anything about that, because I just may or may not.” She said:

I'm not able to [make connections to the art world] with my own work, because I just go, "Wow." I stop often at the end of [making work], and just go, "Holy shit. Look at that." It's like I just saw it for the first time too. ... I don't go back and do corrections. I don't erase anything or fix anything. Whatever's happening is what I work with. ... It doesn't have to mean diddly squat. I find it interesting that other people find meaning in it, but I don't have to. It owes me nothing. It's like, well, I guess if it gives me money that's great [laughs]. But it really just doesn't owe me anything. And, I haven't been hung up on it doing anything else, so that's part of the problem too. You know, [I'm] just getting into this whole thing about, well, [mocking] "Am I going to play with the big boys? Or am I just going to keep being the way I am, which might be perceived as being a little unambitious?" 
Virginia describes her intuitive art-making process, saying it doesn't have to “mean diddly squat." While she mentions that she hasn't been hung up on making connections to the art world, she also acknowledges that not making those conceptual connections has limited the opportunities she can pursue. All these expressions of inner inspiration, beyond concepts and meanings, can be heard as making implicit rejoinders to demands for concepts and language in the art world; indeed as we will see later, those who take an expressivist approach sometimes struggle with hooking into the art world.

While some artists take an expressivist approach, others talked about working with ideas and concepts as integral to their practice. For example, Andrea Campbell referred to her art as a "process of working through an idea." She said, "it's interesting to see the theory and then try to figure out how to visualize it." She described, for example, exploring ideas about self-monitoring and ideas about surveillance. Other artists approached their work differently at different times. Marika Jemma mentioned:

There is the idea and there is the material, and I work back and forth, so I know that if I'm attracted to a material it's because there's something that needs that material or I may have an idea and then look for or invent the material that's needed for it to work.

In describing her art-making process, Marika talked, on the one hand, intuitively, about seeing what happens, because "something ... needs that material." She also talked, on the other hand, conceptually, about first "having an idea" and then looking for the material.

It is further striking that artists discussed conceptual approaches in their art with a view to fitting in with or speaking to the larger art world. In speaking of producing art (and submitting reproductions of it for gallery and grant applications), Marika said, "I have to have produced enough of them to convey a concept, and I have to be able to articulate that concept well enough that people reviewing it can see it." Marika talks both about producing work that conveys a 
concept, and about articulating that concept for "people reviewing it." Similarly, other artists stressed being intentional. Quoting Sharon Katz again:

It's not like I'm saying I just kind of threw these colours or bits and pieces together randomly. I want to be more precise, give more information, saying, 'If I use intuition, this is how I'm using it. This is how I'm accessing it.'

Sharon describes her work not as throwing bits and pieces together willy-nilly, but as working intentionally, accounting for her actions, and conveying "information"- "this is what I'm doing, and this is why I'm doing it, and this is how I'm doing it." Taking it further, she situates her own art-making practice within the larger art world, saying, "I need to know that my work doesn't look like a Renaissance painting. I need to be able to say clearly this is more or less where I situate myself in terms of the conversation that is going on today in visual arts." It isn't just about making interesting work, it's about tailoring it or directing it to the art world. To direct their work, artists need to be knowledgeable about what is happening in the field, which means working in relation to others. As Bakhtin (1986) puts it, written and verbal utterances are dialogic. They happen in relation to and in response to previous utterances (Bakhtin, 1986, p. 91). Accountable artwork - which makes a recognizable utterance in the conversation that is going on - is in dialogue with other accountable art works in the conversation. Echoing this need to be conceptually accountable, Jinny Yu described a shift in the way she approached art-making from "making a lot of work that looked great" to figuring "out what I was trying to say with my work." She said, "I think it's more directed and articulated somehow." In a sense, she moved from an expressivist approach to a conceptual approach directed to members of her community.

What is striking here is not that there are "types" of artists, but that artists don't speak from scratch. They employ particular discourses to organize their work. Artists' ideas about art and art-making are both part of their day-to-day practices and part of the discursive terrain they 
are participating in. Their voices do not exist in isolation (Bakhtin, 1986). In contrast with the idea that a work of art "doesn't have to mean diddly squat," some artists emphasize, so to speak, both meaning and audience when they describe their art as "conveying concepts" to "reviewers," or "giving information," or figuring out in a "directed and articulated" way what art is "saying," or "situating" art "in a conversation." Artists' work is aimed at (and hooked into) the wider art world.

\section{Getting out there}

Getting out there is an important part of artists' work. In this thesis, the phrase getting out there marks the ways that artists participate in the discursive and institutional relations of the art world — in/directly, in/formally and textually. Artists need channels to get their work out there, which happens in relation to others (e.g., purchasers, viewers, curators, jury members) and art institutions (e.g., public galleries, commercial galleries, funding bodies, art schools, academic art institutions). All artists described the importance of getting out there, which I use as a catchall for the ways artists participate in the art regime- - having their art displayed or sold, hosting a studio visit, creating a website/portfolio to show their work, applying for or mounting a show, attending art events, applying for or receiving funding/awards, being critically reviewed in popular publications or catalogues, or simply being thought of for particular opportunities. It can happen formally or informally when a curator says, “Oh, but Beth could do that!” as Beth McCubbin joked when she talked about the importance of being "thought of." Getting out there can also happen when an artist takes the stage to give an artist talk, when her work appears on the floors of a local gallery or when her name appears in the pages of Canadian Art magazine, in a stack of papers on a curator's desk, or in an email in an art professional's inbox. For artists, 
getting out there doesn't happen in an abstract or metaphorical way, but in ordinary practices and relations.

Language fits in to artists' work to get out there in different ways. Just as Virginia Marie said, "the art world is not going to just offer it to me," artists often play an active role in their own getting out there processes. Language is important for getting out there-almost everywhere. Virginia mentioned she even needed to write if she wanted to do a residency in the middle of Newfoundland. Similarly, Mary Porter stressed the importance of speaking about your work. She said, an artist "might have amazing work on the wall, but their ability to speak about what they're doing is not nearly as sophisticated. I know for them they're going to have a difficulty" [emphasis added]. She went on to say, "Within a lot of art spheres, your ability to speak about it sort of gives you that boost." She said, you need to "frame it in terms of writing about it and speaking about it so that you're able to communicate to people in such a way that you're a part of larger conversations in the field." Getting out there involves not just making works of art, but employing particular discourses and participating in particular conversations. The art world isn't just about paint and clay, but also about casual banter and weighty prose. It isn't just about mixing paint, but about mixing art and language.

Much of artists' work to get out there involves language. Again, this can involve casual banter, solicited (and unsolicited) advice, formal conversations, quick emails and formal applications. As I discussed above, some of artists' talk happens in and around the studio. Virginia mentioned receiving more-direct advice from a well-known art critic to stop signing her paintings Ginger, and to start signing Virginia Marie. She said, that an art critic told her:

I could not — or should not—be signing my paintings "Ginger" because it was too informal, and friendly, and not professional. ... I just don't know any of the rules, and I 
don't really care to know any of the rules, but I thought, well, I respect her opinion and know that what she says is true, so I decided that I would change my signature and I did. Just as language can help to form artists' work, language is also part of the way that artists sell their work. Of course some artists have "representatives" to do the selling, but as Mary explained, "I know a lot of people who are trying to make their sales themselves or they only have like partial representation, and so you'll see definitely that there's that more showmanship or persona [that] comes through a lot more." Some of the artists I interviewed talked about selling work out of their home. Anne Renouf talked about newlyweds visiting her studio and spending a couple hours deciding on a painting. Virginia joked about dinner guests taking her paintings off the walls and asking to purchase them. Artists engage in interpersonal commercial language, negotiating with, bartering with, and charming art-purchasers.

While artists' more-informal talk in making and selling work was, of course, essential, the sort of relationship between work and words that was most striking in interviews, had to do with the writing and speaking that artists do when getting out there in an institutional sense. In a sceptical, distancing account, Beth McCubbin opens up the actual work involved:

To be able to continue [to work as an artist] requires a whole bunch that I don't want to do. I just don't. I don't like having to jump through the hoops, and I don't like having to train myself in order to write properly so that I can get those grants, and what would require the training to write properly to get those grants means that I have to start going to an awful lot of art shows. I have to start talking to people. I have to start moving around in the art world, and reading people, right? I don't wanna. I just don't want to do that work that is required.

She refers to jumping through hoops, getting training to write properly, getting grants, attending art shows, talking to people, moving around, and reading people as "work that is required." Her notice of the activities involved centres on participating in the institutional art sphere, and on hooking up with art institutions. She makes explicit the institutional connections involved - for which "writing properly" and, as we will explore, going to art school are central. 


\section{Academic art training}

Receiving academic art training is useful for getting out there. In recent years, many artists have been pursuing professional fine art degrees in universities including in Bachelor of Fine Arts (BFA), Master of Fine Arts (MFA), and, most recently although to a lesser extent, $\mathrm{PhD}$ programs. Many artists talked about their work in and around academe, particularly in relation to language intensive, intellectually rigorous MFA programs. The MFA program is sometimes dubbed a 'wrist up' writing intensive program (Thornton, 2008) as it often focuses more on written/spoken discourse than on studio practice. Students are required to produce various written and verbal genres to be successful (Garrett-Petts \& Nash, 2009; Sefton, 2006). As Mary Porter mentioned, "A big component [of the MFA] is preparing a written document to pair with the presentation of your visual work."

While some artists didn't personally undertake professional training, they pointed out it seems like a necessity in the art world. In a remarkable exposition, Beth McCubbin recognizes that having "language tools to go with your practice" is the/one product of academic art training, and that while such training seems to her to threaten "contamination" or "channeling," it also determines "opportunities" in the art world:

It is a crucial component of the art world right now almost to have gone to art school, because you need to been have taught the language tools to go with your practice.... They do give you a little practical material experience, which is awesome, but really what they're doing is teaching you to be a functioning artist with the written component and the verbal component and the connections with various people in order to further your career. ... And, I chose not to go to art school for particular reasons, because I didn't want to be stained or like contaminated by that - by the channelling. It's valid. I don't mean to knock it and it's very useful, and I'm shooting myself in my own foot for being this way, but in my mind it's just too much influence of stuff that I don't want to have to do that. ... And, now my contemporaries who went that path are living in a certain way, and I'm in a different place. It's just kind of curious to see it. They have more gallery opportunities. They have grant opportunities. They have more travel opportunities. Like, all kinds of opportunities. That comes with being able to be part of that world. ... You 
have to be able to talk to people, and write, and describe your work, and appeal what you want to do to somebody else. You have to be able to sell it, and that's training. Some people, sure, are born sales people and love talking about their stuff, but if you're not born a salesperson and don't love talking about your stuff, then you gotta go to training ... It's kind of funny, but I think that's just kind of reality. I don't think it's necessarily bad. I don't think anybody is a sell-out, because they've had training. That's smart. The market demands it, or the big business, or whoever has the money.

Beth describes the ways that MFA programs "shape you to be somebody who can function in the art world." She highlights the importance of having "language tools" "to talk to people, and write, and describe your work, and appeal what you want to do to somebody else." Similarly, the MFA graduates I interviewed talked about being shaped in particular, professional ways by their education. They viewed it as beneficial, and stressed that professional art training helped them to professionalize and to communicate. For example, Andrea Campbell said pursuing a BFA means “It's something you've chosen as a profession—not just a hobby." Echoing this, Mary mentioned, "Doing the MFA really just cemented the professionalization of my art practice." Artists who had graduated from MFA programs also stressed that the program helped them to be able to speak about their practice. Quoting Sharon Katz:

You get a grasp of the concepts quickly. That's what I would say is the most important thing in the MFA, is learning how to speak about your work. ... I think the MFA speeds that time up. It compresses it. You know-in the two years you probably get ten years of doing it on your own. I know for me, it compressed it and made a huge difference for me. I've definitely noticed a change with in the way I communicate about my work. I think I write more clearly now. I think I write more knowledgably about my work. I think can defend my thinking in an argument much better than I could before. ... I am more able to be in conversation with fellow artists, to engage in discussing art, to engage with other ideas - instead of just my own ideas. The wider conversation. I can engage more broadly now.

Here Sharon describes how she got a "grasp of the concepts quickly." She also describes how MFA training helped her to be able to "engage more broadly now" in "the wider conversation." Along the same lines, Andrea Campbell stressed the benefits of art education. 
Janna: Do you feel pressured to know art theory or to know what's happening in the Canadian art world?

Andrea: I think throughout school, even in a Master's level, you're encouraged to look at different artists and see how they relate to your work or how you position yourself.

Whether or not you talk about them in an artist talk, I think it's always really important to know and to reference. Somebody will bring it up if you don't. I find it's really interesting too. I like trying to keep up as much as I can on what's happening, just to kind of understand trends and different things that are happening. More exposure, I feel, makes you better an artist. The more you see.

Janna: What is the experience like of speaking or talking in that way?

Andrea: I think it's something that takes a long time to develop. Maybe even in undergrad, it's more like trying to get the vocabulary within the arts, but I think once you start to learn that - as you go through a Master's and working - I think that knowledge is there, but it becomes more important to develop your own voice within that. Not just always referring to theorists or other people, but trying to really understand why you make art. I think that's more difficult than you think at first. I found it takes a long time to develop throughout the years. You're kind of absorbing everything at first-learning techniques and theories and everything else — and it needs to sit for a little while.

Andrea characterizes her work as looking, relating, positioning, knowing, and referencing. She talks about keeping up as much as she can, understanding trends, and exposing herself to the art world. She stresses the importance of getting the vocabulary, and developing her own voice within that. She stresses the importance of her academic art education in the process.

While many artists viewed having an academic art education as essential for professionalizing and communicating, there was a tension. Some artists really felt they were being excluded from the art world without the language training. As Beth McCubbin described, "I'm left shooting myself in my own foot" and without the gallery, grant and travel opportunities that come "with being able to be part of that world." While some artists described the advantages of their academic art education and others talked about the disadvantages of not having gone to school, others still poked fun at the absurdity of the academic (jargon-heavy, overly-conceptual) writing. Art critic Sky Goodden referred to it as "trope-istic writing" or writing with "academic pretense," which she characterized as "phrasing that's pretty common to the art world like 
subverting, challenging, engaging in ideas of, that kind of thing, where you're really putting at a distance the object from its activity." Some scholars have dubbed this jargon International Art English (Rule \& Levine, 2012), and have analysed its origins and dissemination.

One way or another, all the artists I interviewed describe an emerging art world which is more conceptual and in which an expressivist practice is harder to sustain. With the growing prominence of degree-granting art universities and with the growing prominence of textually mediated and institutionally coordinated art relations, art is shifting from an expressivist practice to a conceptual endeavour. Petra Halkes said, "I think that people who are not comfortable with this shouldn't have to feel that they have to go and get their MFA, but that seems to be the case right now." Similarly, curator Fynn Leitch mentioned:

[Having an MFA] feels like a requirement in the way that the infrastructure currently exists. It's so blatant when somebody hasn't gone through the system, and it doesn't necessarily need to be an MFA frankly, because there are some grads that get out of their [BFA] undergrad and maybe it takes a year or two, but man, they've got it, and I don't know how they have it, but they do. There's something about the Canada Council, the Ontario Arts Council and the way that artist run centres have developed, and art galleries as well- -though I think in some cases to a lesser extent-that really preferences that academic experience.

Fynn describes how having an MFA "feels like a requirement" in an art world that increasingly "preferences the academic experience." We can see this shift in MFA programs' focus on language training and in the ordinary ways that artists speak about their work. We can see this in the way Beth McCubbin says, "What's the most important thing in the art world? Well, you have to be trained how to talk the talk, and write the language. That seems to be the most important thing. Making art is the given." We can also see this shift in the way Andrea Campbell says, "I remember a prof in my undergrad, saying, 'Nobody really cares if you make art. It's not 
necessarily a necessity, so why are you doing this?'" Further, we can see this shift in the way

Sharon Katz emphasizes being an artist isn't about having an (expressivist) studio practice:

For an artist, you can go to school and you can learn how to draw or how to paint, but what does that tell us about what you're going to paint? Nobody is paying us to paint. Nobody is saying, "Well, you learned how to draw with charcoal and pencil... and you learned how to paint with oil, and I need you to do a painting of my house..." Artists are creating the audience, they're not responding to a fixed need. ... We are knowledgeable about the materials, but just because we know how to mix oil paint doesn't mean anything. ... We're not necessarily solving a problem; we're engaged in communication and in translation through other material means. All kinds of things that are much less structured, and very hard to measure.

Sharon describes an art world where mixing paint doesn't mean anything, an art world where artists are engaged in communication. Like Sharon, visual artists today are working in the institutional art sphere that "preferences the academic experience" (as Fynn said). This art world takes place across various discursive realms. One such realm is the public gallery.

\section{Getting out there ... and into public galleries}

Of the many institutional and commercial connections in the art world at large, most artists stressed the importance of showing in public galleries. Jinny Yu said, public galleries are “recognized by my peers as being a legitimate exhibition venue." Showing in a public gallery is not only a way of getting out there, it is also an endorsement from the contemporary art community, a way of making money, and a way of showing markers of being a professional artist. Showing in a public gallery is an achievement that appears on artists' CVs, and occasionally comes with the opportunity to have work reviewed. Artists typically use language to get in (e.g., exhibition proposals), there is language involved in the exhibition itself (e.g., artist talks, writing on the wall), and there is language to follow as artists' work is typically taken up, written about or talked about afterwards. Public galleries are a hub in the Canadian art world, and a realm where art and language conjoin, commingle and sometimes collide. 
Artists approach public galleries in different ways. The expressivist/conceptual divergence in artists' work to make art sometimes appears in their efforts to get out there and into galleries. Some artists took a more-conceptual approach to getting out there and into public galleries. For example, Mary Porter mentioned it is essential for an artist to find "ways to articulate projects and the conceptual underpinnings of those projects." Sharon Katz described ways that communicating about art is sometimes collaborative in the gallery sphere, saying:

If a curator wants to talk to you about your work, you need to be able to speak coherently and clearly in a language that they can understand. ... If you sort of leave it up to them, then you don't really have a say. You want to participate in that. As an artist, I want to participate in that. I want to be really clear about what it is.

Sharon makes explicit her desire to participate in the discourse and to collaborate with curators. While some artists viewed the conjunction between art and language as a natural part of their work in public galleries, others struggled with employing conceptual art discourses. Some artists talked about making up something more conceptual to go with their work and about "making some adjustments [to their writing] or even hiring somebody else to make the adjustments" (as one artist described it). While Beth recognized it is a part of an artist's job to collaborate with curators, she somewhat distanced herself from the process. She said, "You know, the artist will say, "I have this idea," and [the curator will] say, "dah dah dah dah and dah dah dah dah." You know? It becomes a collaborative effort with the people that have the money." While she referred to this collaboration as "kind of what happens," she said, "I don't like that stuff. Unfortunately, the essence of me is about none of that. [I'm] sort of about objects for what they are or people for what they are not about having to prove to somebody that you are something."

Irrespective of artists' attitudes to their (language) work in public galleries, it is clear that communicating through written and spoken discourse is crucial in getting out there and into 
public galleries. As a part of their work in public galleries, artists connect formally and informally, attending exhibitions and artist talks, introducing themselves, applying for exhibitions, hosting studio visits, planning exhibitions, installing shows, and scheduling events. When applying formally to a public art gallery, artists typically send in exhibition proposals, which include digitized reproductions of their work and written texts (e.g., artist statements, bios, CVs). While artists are free to interpret proposal requirements broadly and to write as they see fit, there are conventional ways for writing both bio statements and artist statements. As we will see, the artist statement is typically where artists display their conceptual seriousness while the bio statements is where artists display their professional standing. It is also worth mentioning, artists do not write from scratch. To produce these written texts, including, artist statements, gallery texts and popular publications, artists often refer to the work of others to get a sense of how to write their own.

\section{$\underline{\text { Artist statements }}$}

Artists are typically required to include artist statements in their exhibition proposals. In speaking about the social purposes of the artist statement, Sky Gooden, who leads writing workshops for artists, described them as typically written by artists in order to "seek out financial patronage or support for your exhibition practice or [artist] residences." She mentioned the audience is typically "granting bodies, exhibitions, artist residencies-from time to time although very rarely—collectors." She said, "if an artist is applying to a commercial gallery or artist-run gallery for the first time seeking exhibition or representation, that would be a viewing audience as well.” Quoting Sky again:

By and large, it is an internal document. I mean, I'm being somewhat optimistic here, because this is how I would like to see it be used more than anything. In the top sort of registers of the art world, where people are working most professionally, it's really not 
meant for public consumption. It's meant to inform those who will go on to curate and write about the text at a more-polished and removed level, right? It's meant to give small cues or work as small-change currency, aligning a professional to the artist's intent. But of course the intent is not the only important factor in knowing the artist's work. Largely, in fact, I think it's secondary to an experienced eyes' and minds' reaction and response and positioning of that work.

So at times, the artist statement isn't meant for the viewing public but to inform the polished and removed writing of art professionals working internally and professionally. The artist statement "provide[s] us with a context for viewing," "both directs the viewer's gaze and indirectly announces or affirms the artist's rite of passage" (Garrett-Petts \& Nash, 2009). While most galleries don't specify what should or shouldn't be included in the artist statement, they tend to take on standardized forms. As we will see below, the artist statement is a space for artists to demonstrate their conceptual seriousness, and to make clear connections between work and words.

In reading artists' actual written utterances, we can learn about the art world they are a part of. With a view to considering how written utterances take part in the discursive and institutional relations of the art world, let's attend to the artist statements of Mary Porter and Beth McCubbin. Mary Porter's (n.d.) artist statement reads as follows:

The longstanding interests that have shaped my art practice have been an inquiry into the built environment and landscape; an interest in utopian and dystopian imagery and narratives; a fascination with the idea of the sublime, that which we can imagine but never fully represent or understand; and how the history of painting is tied up in all these things.

The impetus for my practice has always come out of looking at the built environment to glean some sense of the culture that created it. My understanding of the landscape is formed from my daily experience, from memory, and from the spaces and places that exist in our collective imagination through popular culture. Like the cultural geographer Denis Cosgrove, I believe that "landscape is not merely the world we see, it is a construction, a composition of that world. Landscape is a way of seeing the world."

Beth McCubbin's (n.d.) artist statement reads as follows: 
I build works of art primarily from clay and from concrete, both alone and in combination with other mixed materials. I create single works or site specific installations comprised of multiple pieces. My installations often require the use of different materials in order to convey a particular meaning, and I very much enjoy the challenge of this.

Presently my sculptures are concerned with expressing figurative movements. They are carefully crafted to direct the viewer to their forms in order to find meaning. My desire is to create sculptures that not only express a recognizable action, but also instil a particular feeling or thought.

Part of my artistic purpose is to produce works made from environmentally sound materials, recycled or extracted without great impact upon the earth, and using materials that are common, familiar and widely available. It is very important to me that art be approachable and accessible to all people and I feel that perhaps by making it with recognizable materials I am able to assist in this effort.

Both artist statements do conceptual work; both apparently address the expectation to integrate art and language and to convey a concept. There isn't one section devoted to the art and one section devoted to the ideas. Instead, the artist statements integrate art and ideas, sharing how the work embodies a particular concept or connects to a particular idea. For example, Beth talks about "convey[ing] a particular meaning" and about "expressing figurative movements."

While both artist statements integrate language and art, and talk about the work conveying a concept, they don't do it identically. Mary positions her work as a conceptually ordained, scholarly production. Taking a conceptual/academic approach in her artist statement, Mary talks about the "interests that have shaped [her] practice," and shows how her work started with ideas. Much like an academic researcher, Mary refers to her art as "an inquiry into the built environment," discusses the "impetus for [her] practice," and closes with a quotation from a cultural geographer. The way that Mary describes her practice connects well with the way curators describe looking for work that is intentional. As gallery curator Fynn Leitch said:

If you want to think about materiality you totally can, but you need to know why you're thinking about materiality, and you need to know what that materialist movement is and why that's happening. It has to feel intentional. 
Fynn stresses the importance of intentionality and self-awareness. Aligning with the conceptual art world, Mary makes explicit that her art is a purposeful inquiry with a scholarly impetus. Mary disattends her personal decision making process.

While Beth's artist statement does have traces of the conceptual discourse, she also includes features that are part of her own experience. She doesn't remove herself from the write up. For example, she highlights the actual process of making the art. She talks about building works, creating, crafting, producing and working in combination with other materials. She emphasizes the production of the works. Further, somewhat atypically, she emphasizes her own personal decision making process, saying, "I feel that" and "It is very important to me." She connects her work to herself, to her own intentions and purpose. When I asked her about writing in the art world, Beth shared that, "explaining who you are and why you're creating the works... isn't normally done. ... It's almost too female of a way to do things. ... Male [writing] is not really as much like that. Their purpose is more separated. This is a commentary on the way that it $i s^{3}$." Beth is well aware of the standardized ways of writing (yourself out of) artist statements. Her choice to include her personal decision making process was very much an effort to brush against the system and to resist the institutional pressures to provide an objective commentary on the so-called "way that it is."

In his work on literacy, Darville $(1995,2009)$ draws a distinction between experiential literacy that is concerned with telling individual experience, and organizational or institutional

\footnotetext{
${ }^{3}$ Beth's characterization of writing in the art world as "male" is very much in line with other feminist critiques of conceptual approaches in the art world. For example, in her essay, Nochlin (1971) writes, "we know, in the arts as in a hundred other areas, things remain stultifying, oppressive, and discouraging to all those — women included — who did not have the good fortune to be born white, preferably middle class and, above all, male. The fault lies not in our stars, our hormones, our menstrual cycles, or our empty internal spaces, but in our institutions and our education" (p. 6-7). Along the same lines, Smith (1989) challenged objectified, masculine ways of knowing, reflecting on her experience "becoming more and more sharply aware of the full implications of our (women's) exclusion from the making of the social forms of consciousness (the knowledge and culture) of our kind of society" (p. 38).
} 
literacy that organizes the world through concepts and categories. We can see experiential literacy practices used in the way that Beth describes her own individual preferences, and organizational literacy practices in the way that Mary conceptualizes her work. Interestingly, however, for an artist's work to be funnelled out of her studio and into the discursive and institutional relations of the art world, it needs to eventually take on an organizational form (see Appendix $\mathrm{C}$ for examples of how artwork is written about in exhibition promotional materials). It needs to enact the organizational process. Darville (1995) writes:

Organizational literacy enables people dispersed in time and space to develop complementary ideas and to act in concert towards the people or situations that they make account of, administer, interpret, legislate for. People using literacy to do organizational work simultaneously write, conceptualize, and enact organizational processes. They make up a textually mediated social organization (Smith 1984). (p. 255)

Literacy as a way of enacting organizational processes most certainly plays out in the art world.

As Sky Goodden points out, artwork may eventually need to be written about in a more polished and removed way by art professionals. Similarly, Heather Anderson remarks, "Writing is valuable to an organization, because it means that their exhibition does have a life beyond the space of the presentation." Writing connects the artwork beyond the actual space, hooking it into other organizational processes. For artists, the artist statement is a first "move" in creating an organizational account of their work, entering into the institutional art world, and getting their work "validated by other professionals — other people who are engaged in the conversation" (as Mary Porter put it).

\section{$\underline{\text { Bio statements }}$}

Artists are sometimes required to include bio statements in their exhibition proposals. This written document is sometimes produced by artists when they are applying for funding, applying to galleries and applying to residencies. While some opportunities ask for a CV (in lieu 
of the bio statement), bio statements are often included in public gallery texts, including brochures, websites and catalogues. Some artists also include them on their own personal websites. While artists are, again, welcome to write as they see fit, bio statements are conventionally a space for artists to demonstrate their professional standing, and their certification/recognition by universities, art galleries, funding bodies and publications. With a view to considering how artists' written utterances operate in the discursive and institutional relations of the art world, let's attend to the bio statements of Jinny Yu and Marika Jemma. Jinny Yu's (“General Hardware,” n.d.) bio statement reads as follows:

Born in Korea and based in Canada, Jinny Yu has shown widely, including exhibitions at the ISCP Gallery (Brooklyn), Pulse New York (NY), Scope New York (NY), Bevilacqua La Masa Foundation (Venice), the Kyoto Municipal Museum of Art (Kyoto), the Conduit Street Gallery, Sotheby's (London, UK), Carleton University Art Gallery (Ottawa), the Taehwa Eco Art Festival (Ulsan City, Republic of Korea), the Confederation Centre Art Gallery (Charlottetown), and McMaster Museum of Art (Hamilton). Yu, who is Associate Professor of Painting at the University of Ottawa, was awarded Laura Ciruls Painting Award from Ontario Arts Foundation in 2012 and was a finalist for the Pulse Prize New York 2011. In 2012 Jinny's work was featured in the main space at The Canadian Painting Survey exhibition 60P. She has received grants from the Canada Council for the Arts, Ontario Arts Council, and le Conseil des Arts et des Lettres du Quebec. Jinny Yu has recently returned from her solo exhibitions in Seoul Korea at KunstDoc Art Gallery and Nanji Art Gallery of Seoul Museum of Art. In 2012 Yu's work was included in the ambitious 60 Painters exhibition and catalogue, an overview of contemporary Canadian painting.

Marika Jemma’s (“Enriched Bread Artists," n.d.) bio statement reads as follows:

Born 1963 in West Toronto, enduring a non-descript Catholic childhood and surviving the banality of a whitewashed suburban existence in the pursuit of modest personal debt, Marika left home at 17 to experience the joys of minimum wage, public transportation and a series of rooming houses in various dissociated communities in southern Ontario.

An independent learner, Marika has explored the public libraries of most of the major cities in Canada and on a rainy day in 1982, a greyhound bus deposited her in the city of Vancouver. Due to the works of Jane Rule and Jack Hodgkins, Marika moved to Vancouver Island where she spent the next 11 years pursuing a series of odd-jobs, training as a carpenter and finally graduating from art school in 1991. 
Her first vehicle was a 1969 GMC step-side, short box pick up, painted matte black with a cracked windshield. Her first girlfriend drove a motorcycle. Her first solo show was called "Journey To The Temple" at Xchanges Gallery, Victoria, B.C. 1991.

In 1993, Marika drove back across the country in a 1973 Toyota Corolla, dropped the muffler on a raised railway bed in southern Saskatchewan and ran out of gas in Ottawa and has been here ever since.

Marika joined the Enriched Bread Artists in 1998.

In examining the bio statements of Jinny and Marika above we can learn more about the discursive terrain of the art world that those written utterances are embedded in. Both artists use their statements to position themselves in or in relation to the art world. Jinny positions herself at the centre of the organizational art world while Marika plants herself on the outskirts. Jinny's bio statement makes her professional standing and recognition discursively explicit. The statement details her numerous gallery showings, her work as a professor, her grants, her awards and her publications. While Jinny's bio statement closes by mentioning the medium she works in, the rest of the bio is devoted to her institutional affiliations. In contrast, Marika's tongue-in-cheek account hardly mentions her institutional affiliations. Instead of an institutional, polished account, she talks about life on the ground. She starts outside of the art world, underscoring minimum wage work, rooming houses, odd-jobs, and even a cracked window in her 1969 GMC step-side. When I asked Marika, quite broadly, about writing her bio statement, she said:

It's a bit a flippant, and it is because I don't have academic credentials that I wish tothat would serve me in terms of people who would be assessing me based on my academic credentials - so assigning credibility or not assigning credibility based on - you know-where I went to school, whatever that means. So what I'm trying to say is that learning happens, and education happens, everywhere all the time. So, whether or not you actually have a degree that you paid for is not necessarily an indicator of how welleducated you are or how intelligent you are or any of those things.

Her "flippant" bio statement is a way of thumbing her nose at the institutional requirements and a way of speaking back to the demand to "have a degree that is paid for." She goes on to say, "I think I was a little bit reactive to [mocking] 'so and so studied with so and so and the humphhh 
and did this and that and the other thing." As opposed to Jinny's institutional account, offering a cluster of "recognitions" in awards and gallery showings, Marika offers an experiential, chronological account of her "haphazard path." In referring to her own statement as "flippant" and "reactive," Marika points to (by poking fun at) standardized ways of using language and of navigating the institutional art world. Again, these texts display the workings of the art world.

When I asked Sky Gooden about whether or not an artist's identity should be communicated in her writing, she pointed out how, in her view, it can be a problem to have parts of a person's biography included in writing about artwork. She said:

Oh, you mean, like, "I was born in, I suffered abuse from?" Well, I think identity is a slippery term and probably one that should be avoided in this context. I think that's biography, right? Biography plays its part. An artist's bio is different from an artist's statement for a reason. If you look at work that is entrenched in certain genres, so to speak, like, post-colonial theory or relational aesthetics ... then it becomes difficult for those biographies not to be read into the work, and oftentimes the artists encourage that link. I think that can be a problem though. It can make for lazy art. It can make for lazy viewing, and sympathies become manipulated such that we're linking admission of - you know-difference to the production of good work, which is not a given by any stretch of the imagination, so I'm hesitant about it. I would say, too, that we have to let art exist in a space much like theater and the performing music arts and any number of other fields with varying kinds of instruments at play in them. We have to let art exist in a space where the product is not necessarily linked to its author as demonstrative of that author's experience. The work, in essence, should be allowed to sort of be positioned at a remove from that biography and be performative of any number of other truths that that author wanted to pen-so to speak.

Here Sky pushes for artwork to be presented at a remove from the artist's biography. Sky asserts that including biographical information and admitting difference can make for lazy art, and can interfere with the production and presentation of good work. She suggests that, for art to be taken seriously, it should exist in a space much like theater and performing music. She makes explicit that, in the art world, the "conversation" isn't about the artist's individual biography, but about 
performing other truths. Similarly, gallery curator Fynn Leitch mentions art eventually needs to be written about in a removed way.

It's up to the person whose writing to determine whether or not they can write about it appropriately and remove that personal relationship from the writing ... If you're going to produce a proper, critical piece of writing you have to suspend that - you have to be able to distance yourself from the person and talk about the work.

Fynn talks about critical art writing that centres on the work itself-not on the artist's personal relationship with the writer. She refers to this as writing "appropriately." She stresses that the “conversation" in the art world isn't about the writer's relationship with the artist. The conversation needs to be distanced from the artist to be proper and appropriate.

The juxtaposition with Jinny and Marika's work is between experiential literacy that is "anchored in lived experience" and an organizational literacy that is "anchored in organizational or professional processes" (Darville, 1995, p. 250). Offering an organizational account is both a way of getting out there and a conveyance of professional standing. Again, we can see in Appendix $\mathrm{C}$ the sort of organizational accounts that are taken up in public gallery texts. To get out there, artists, like other professionals, "employ textual realities to mediate the details of their daily practice" (de Montigny, 1995b, p. 209). Through their writing, artists "perform discursive work and produce a continuous series of presentations of self which demonstrate the proper professional and organizational motivation" (de Montigny, 1995b, p. 216). They show their own institutional standing while also bolstering the standing of the institutions they are a part of. Their textual practices, along with producing their own legitimacy, produce the legitimacy of the institutions (Rusted, 2006, p. 121). 


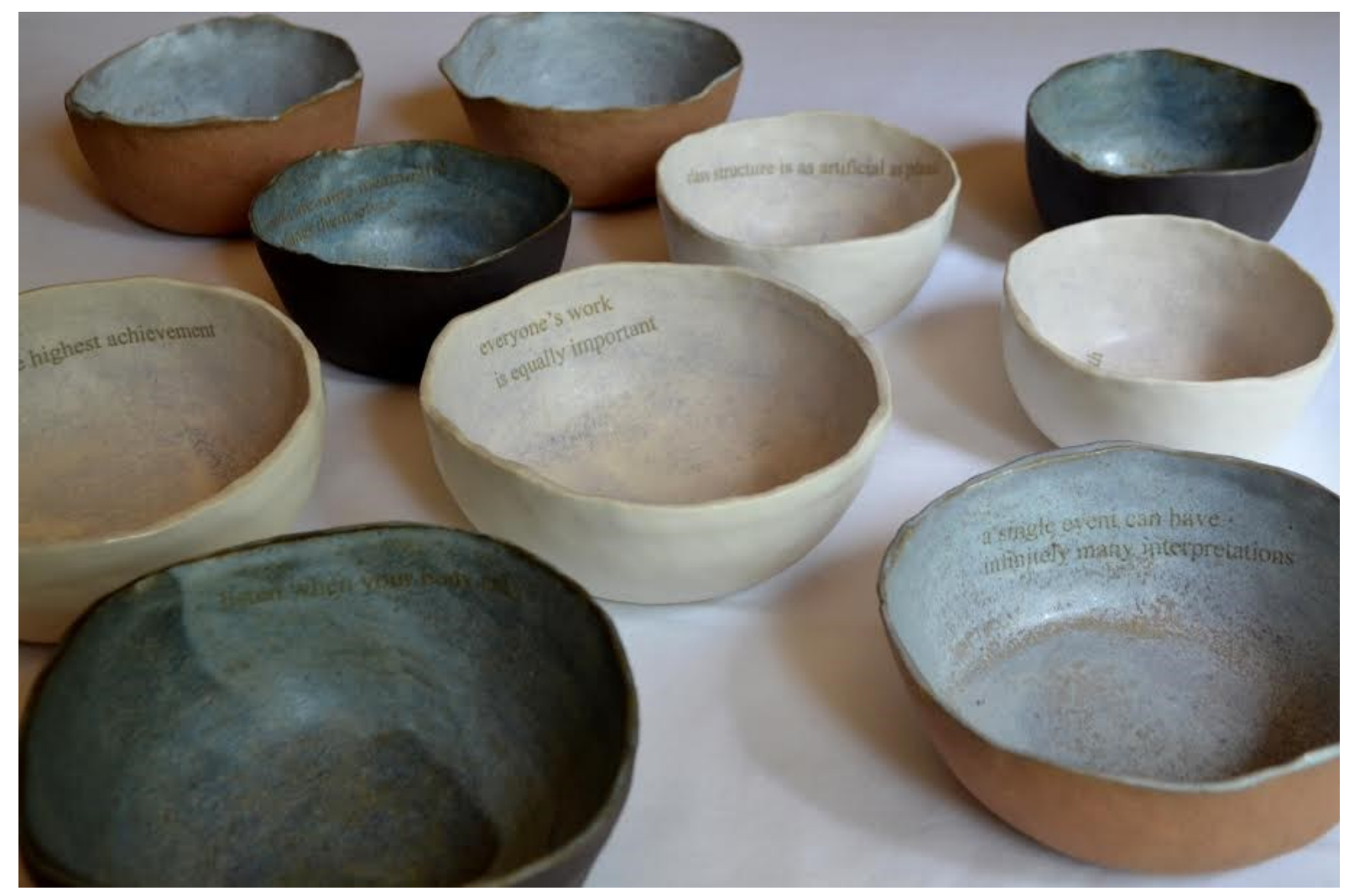

Figure 6. Beth McCubbin, bowls of truisms, 2014, porcelain, stoneware and black clay, glazes and iron images, courtesy of the artist.

\section{Material resources for doing art}

Just as Mary Porter, quoted at the beginning of the chapter, stressed the importance of having money, space and time, other artists recognized those resources are essential for being able to put the brush to the canvas or fire up the kiln. Artists need money/funding, space, and time to be able to make art, get out there and get into public galleries. Artists need to have financial support in order to foster their careers, which can, of course, happen through getting out there (e.g., selling their work, applying for funding, showing in galleries). Beth McCubbin joked "people will buy cups," when describing how selling her art is an essential part of her work as an artist. Having money is a major advantage as it means an artist can put her time into making art (rather than marketing it), and that her "production doesn't have to depend on the market" (as 
Jinny Yu remarked). Money also impacts an artist's ability to further their career. For example,

Virginia Marie shared she is sometimes faced with deciding whether to sell her works individually or to save up enough works to have "something that makes sense as a collection." She said, "I'm at a bit of a crossroads, because I could really use the money, of course, on the other hand, if I don't have a collection of something that makes sense as a collection, it's not really fair to present to a gallery or anybody either." For artists, money is not only payment for getting out there, it also has a direct impact on how they can get out there. Artists work within a larger art market. Petra Halkes, for example, talked about an art world where works become commodities.

Janna: How does the work of local artists connect to the larger art market?

Petra: It's a matter of everyone, I think, is implicated in the system. It's a capitalist system. I don't want to sound too communist here, but [laughs] you know, it's a system where the paintings and the art works become commodities. If it happens on a higher level $^{4}$, typically it trickles down to all levels, but it's a really difficult question, because I know painters have to make a living too, and they have to sell their paintings to do that, so...

Janna: Do you sometimes feel like you're making a commodity?

Petra: Yeah. Yeah, I do actually. Of course it's not really an urgent question at my level, because there's a whole hierarchy in art where commodities - you know-where commodities become more rare. A commodity? Well, I suppose you are. In a practical way involved too, you know. This afternoon I just finished [going to] 'Three Gallery' to drop off our contributions to the fundraiser-you know - but there are a lot of questions about that. Some people won't participate because they feel that it lowers the prices, because there are collectors that will go to these fundraisers and get a really cheap work of art, because they're all done by auction and they usually sell far below the price that you would get in a gallery.

Janna: So if you were putting them in twenty auctions it would lower the price?

Petra: They feel that it lowers the price for everybody, because you're basically underselling. Even at our level, you can't escape that kind of capitalist thinking. It's just; it's the system. It's in the supply and demand. If you flood the market with cheap

\footnotetext{
${ }^{4}$ For more information on the high-art market Petra describes, refer to Blakenfeld, von Zeppelin and Adams (2009), Dimitrakaki (2013), Fraser (2012), Plattner (1996), and Thornton (2008),
} 
products, like, even if it's for a fundraiser, you're damned if you do and damned if you don't, because if you don't contribute to these very worthy causes it's not really very nice either, is it?

Here Petra makes explicit that she is working within a larger, capitalist art market, where "painters have to make a living too." She talks about supply and demand, and about the tension between flooding the market with cheap products and contributing to worthy causes. She makes explicit the importance of money in the work of visual artists. As Petra's comments exhibit, there is a political economy of art. In an economist's terminology (Roubini, 2015), “art is an asset class." While my analytical focus is on the conjunction between work and words in the art world, it is important to underscore that artists' and curators' work is part of an economic art market. This art market is replete with many market participants, including, "art galleries, auction houses, and various dealers and intermediaries [who] take part in buying and selling art" (Roubini, 2015).

Having time to make art and to get out there is also crucial for artists. For example, when I visited Beth's studio, she pointed to a piece that took 48 hours to complete and nearly three years to learn the technique through trial and error. Many artists need to fit their work to make art and get out there into other life commitments, including working side jobs or caring for family members. Marika, for example, talked about working "under a production kind of schedule," and about making her time count. She said:

Often I do work under a production kind of schedule, because I have all these other parts of my life that I have to manage. So I know that I may have forty minutes in the morning and I have to make them work, and the next day I may have two and half hours, but it's got to count, right?

Emphasizing the importance of time, Marika also described how it is easier to be an artist now that her daughter is in school. She said, "I am so much happier just in the last couple months, 
because I can actually come to the studio, and actually be an artist, and get back on track, and start applying to shows, and all that." Her ability to actually be an artist took time.

Along the same lines, artists need physical space to work. When I visited her studio, Petra Halkes was quick to point out the importance of physically having a place to store her paintings. Her own studio was full of countless paintings, including from past and future exhibitions. Studios can also be important places to entertain curators or to give outsiders a sense of the practice. As Beth explained, it is a luxury when an artist has a nice studio that they can take pride in and invite curators to. Again, time, space, money are essential material resources that are very much dialectically related to getting out there. Having money, space and time not only supports an artist's ability to get out there, but also come in return for getting out there.

\section{Discussion}

This analytical chapter has traced how artists' work encompasses language. Artists mix paint with prose, art with language. Again, this doesn't happen in an abstract way, but in their ordinary material and discursive practices. Art mixes with language in artists' efforts to make work, to get out there, and to get into public galleries. Artists organize their work in different ways, taking on expressivist and conceptual approaches. Artists also take an active role in their work to get out there, which centrally involves making textual and linguistic moves to hook up with galleries, grants and "the conversation." And, these textual and linguistic moves happen dialogically_in relation to and in response to previous utterances (Bakhtin, 1986, p. 91). These utterances display conceptual seriousness and professional competence. These utterances tell us — not only about the work of artists — but also about the art world they are a part of, an art world which is conceptual and reputable and in which an expressivist practice is harder to sustain. 
While I have traced a conceptual or expressivist divergence in art-making and getting out there, what has been most striking isn't the orientations of individual artists, but the ways in which their language work is organized within the larger art world. Their language is adapted and shaped through producing talk and meaning for others, and, in turn, giving shape to a particular social world (Goodwin, 2006 as cited by Gutiérrez, 2008, p. 153). And, they don’t speak from scratch. They participate in, take part in shaping, play with and poke fun at the discursive conventions of the art world. They enact the institutional art regime through their work, not just their material work but also their discursive work to conjoin visual images with conceptual descriptions. That conjunction is striking both in the ways that artists make art and get out there, and in the ways that those work processes articulate to, and are shaped within, practices and relations that extend beyond them. This analytical chapter—on artists' work—-both opens up the institutional art world, and opens further windows on to it. 


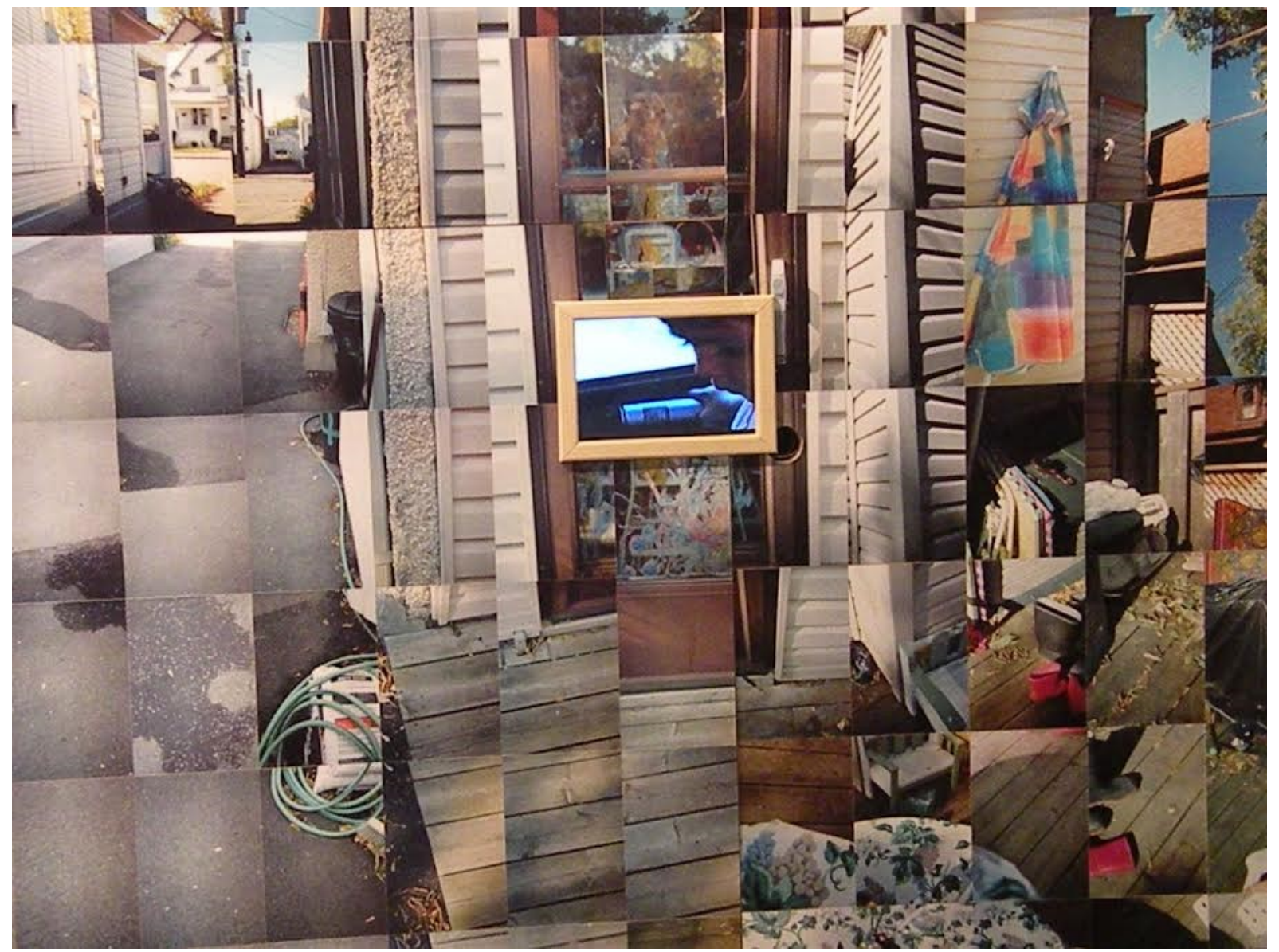

Figure 7. Marika Jemma, Backyard, 2012, photo mural installation with video insert, 12 x 8 feet, composed of 576 individual $4 \times 6$ snapshots taken with 400 iso colour film, representing a 360 degree view of artist's backyard, courtesy of the artist. 


\section{Chapter 5: Institutionally coordinated art world}

Chapter 4 investigated artists' working experiences with a focus on the conjunction of visual art works with language/writing, and with a view to opening up the larger terrain of the art world. I traced artists' work to make art, to get out there and to get into public galleries. I explored how artists' language and writing work — from hobnobbing at events to writing bio/artist statements — are clearly aimed at what they referred to as "the conversation," or "the art world." This chapter decentres artists themselves to focus chiefly on curators' work, on the conjunction between art and language in curators' work, and on how that work is part of the coordination of the art world at large.

My focus on curators' work in public galleries is deliberate. While the art world includes coordinated connections across numerous sites, the public gallery figured prominently in the accounts of artists. Much of artists' work to get out there involves engaging in and participating in public galleries: applying to exhibitions, attending events, producing work/words, installing shows, and giving artist talks. The public gallery is a hub, and curators work as mediators coordinating different sites. As Catherine Sinclair put it, "We are, as curators, very much mediators or producers who just pull different parties together." When asked about the writing she does as a curator, Fynn Leitch made explicit how language is central in her curatorial work.

The writing that we do plays out on a number of levels really. It definitely plays out in terms of how we get our funding, because we write some of the exhibitions into the grants themselves, but also we have to present ourselves publicly on a scale that's within the immediate community, so directly to our physical audience, but then also more broadly to the province and to the country in terms of how we speak to the general conversation on contemporary art, but also the government that funds us, the artists who might want to show with us, and the people who work for the funding agencies that fund us, and, the people who sit on the juries that ultimately decide how well our grants should be received. So, there's writing in terms of grant applications, but then there's also writing that physically exists in the gallery and then there's writing that exists on the 
internet and in any exhibition promotion material. Aside from, of course, catalogues and things like that, which are maybe more obvious.

In this eloquent description, Fynn describes her practical engagement in the social relations of

the art world. She gives expression to, and so opens up to analysis, a field of discursive activity, in which she takes part by writing at a "number of levels" — addressing the immediate community/audience, online audiences, artists that might want to show, funding agencies, and "the general conversation on contemporary art."

As Fynn illustrates, curators' work is complex, multi-faceted, and fundamentally involves language and texts. As a part of their work, curators read/write various texts and participate in various coordinated work processes "across discursive sites" (Smith, 1999, p. 59). An overview of curators' work is featured in Table 3.

Table 3

Curators' coordinated work

\begin{tabular}{ll}
\hline $\begin{array}{l}\text { Follow and take part } \\
\text { in the local art scene }\end{array}$ & $\begin{array}{l}\text { knowing "who's who," doing studio visits, offering informal } \\
\text { advice/mentoring to local artists, attending local arts events }\end{array}$ \\
\hline Mount exhibitions & $\begin{array}{l}\text { making decisions about who/what to show, reviewing proposals from } \\
\text { artists, inviting artists to show, installing shows, organizing logistics, } \\
\text { scheduling programming (e.g., artist talks, exhibition openings, events, } \\
\text { auctions, fundraisers, guest speakers), reaching new audiences, writing } \\
\text { exhibition promotional materials for digital and immediate audiences } \\
\text { (e.g., brochures, introductory texts, "didactic panels") }\end{array}$ \\
\hline $\begin{array}{l}\text { Maintain intra- } \\
\text { organizational, intra- } \\
\text { gallery affairs }\end{array}$ & $\begin{array}{l}\text { dealing with other staff (e.g., executive directors, fellow curators, } \\
\text { preparing/overseeing jury members, ensuring that the shows and } \\
\text { perhaps the local scene-monitoring are in accord with the gallery } \\
\text { mandate, preparing annual reports, liaising with board of directors }\end{array}$ \\
\hline $\begin{array}{l}\text { Maintain extra- } \\
\text { organizational affairs }\end{array}$ & $\begin{array}{l}\text { securing corporate and public funding for the gallery and for particular } \\
\text { shows (including from Canada Council, Ontario Council for the Arts, }\end{array}$ \\
& $\begin{array}{l}\text { Heritage Canada and other municipal/regional sources), attending to the } \\
\text { priorities of funding bodies, applying for grants, producing subsequent } \\
\text { reports, handling public/media relations, soliciting media coverage }\end{array}$ \\
\hline
\end{tabular}




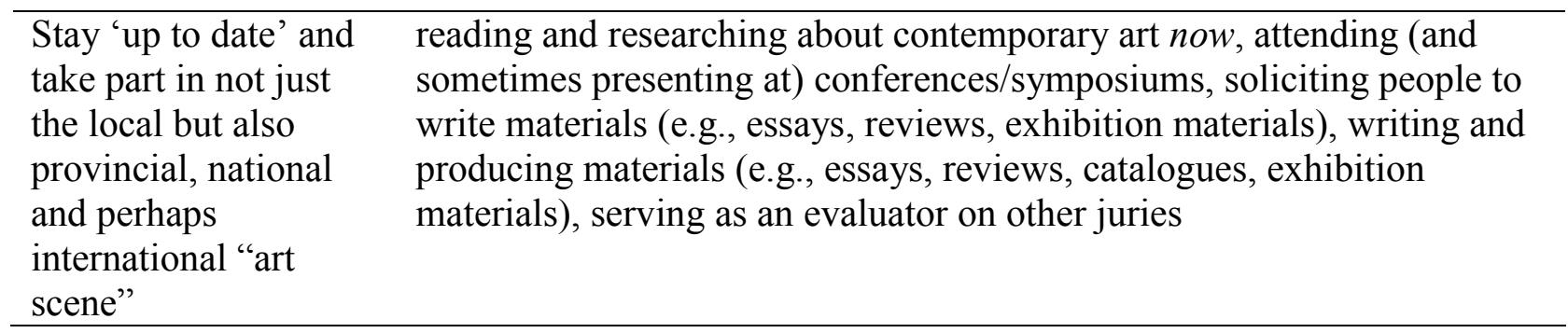

Curators' work mediates or stitches together what artists do with what others do in a wide variety of sites. They use written and spoken discourse to stitch themselves (and the work of artists) into larger conversations. While some of this language work is visible (like the writing on the wall of the gallery), much of curators' work happens internally or behind-the-scenes. One curator said, “It's not glamourous," and described spending 99.9\% of her job reading and responding to emails. Moving forward and bringing together complex sequences of activity, I will examine curators' work to make decisions about who/what to show. I will attend to curators' conceptual practices with a view to opening up the regime.

\section{Curators' conceptual practices}

A key part of curators' work in public galleries involves deciding who/what to show. This work happens both informally as curators come to know the art world locally and beyond, and formally in the evaluation of artists' exhibition proposals. Work processes vary between galleries. Some galleries use a jury system, others use an invitational system, and some use a combination of both systems depending on the time of year. With a juried submission process, the jury selects artists to show from a pile of submissions. With an invitational (or rolling submission) process, curators typically invite or solicit artists to show. Sometimes curators ask artists to send in a proposal, and other times they rely on their own knowledge of artists or on artists' online portfolios. 
When applying formally, including as part of a jury process, the routine is for artists to submit proposals, which typically include written texts (e.g., artist statements, bio statements, CVs) and digitized reproductions (a.k.a. samples of images or videos). Aside from juried evaluation processes (where proposals are selected out of the pile), artists' gallery submissions do not stand alone, and are only rarely like an "application" that is "sent in" and then "accepted." One curator mentioned receiving between 100-140 applications with no more than ten spots to fill. Another mentioned receiving close to fifty applications a year with six spots to fill: "We do get artist submissions, but it's sort of rare that we'd end up going from that when they're just cold calls, because there is such a huge list of artists who we just know we need to do their show." While a "cold call" submission may not lead to immediate acceptance, it may lead to being kept in mind or taken "into account when planning studio visits." Submissions, even if not accepted, that is, feed into curators' local "work knowledge," which is accumulated as they focus on "the local art scene" and "keep an eye on" or more generally monitor what's going on in their area.

\section{Work, words, reputation}

When making decisions about who/what to show, curators refer to the artists' work and words - the visual images and texts that are included in formal proposals and in artists' online portfolios/websites. The relationship between (or the fusing of) works and words is clearly very important, and curators - like artists, as seen in the last chapter - are attentive to it. All the curators that I spoke with emphasized the importance of the work itself. Heather Anderson was quick to point out, "I think the most important thing is that [visual artists] make really great work," and "first and foremost, the artwork has to be really interesting." Similarly, Jason StLaurent, noted, “Jury members aren't fools - even though they're not experts in semiotics they 
know how a work communicates visually." Nevertheless, while most curators granted such importance to the visual work itself, the writing was also important, sometimes surprisingly. In reflecting on her work process at Artspace, Fynn Leitch mentioned, "In the way that I've run juries, it really preferences the writing." She described initially sending the jury written proposals, including artist statements and bio statements: "They read without seeing any images, and they read that before meeting any of the other jurors."

In evaluating artists' submissions or making decisions about exhibitions, curators employ particular conceptual practices - particular, professional ways of looking. In describing this aspect of their work, curators stressed the importance of a "concept" or "idea," which is produced/enacted in the artist's work/words, and, in turn, legible by curators (as well as jury members and others), interpretable by them, and available for evaluation. Catherine Sinclair referred to this as looking for work that conveys "conceptual seriousness," evident in art and ideas aligned. Jason emphasized that jury members need to see "a relationship between what you're writing and what they're seeing on the screen." He highlights the connection between work and words, stressing the importance of work that communicates both visually and in relationship with what the artist writes. He further makes explicit the connection between the concept (the way that the work and words integrate) and the evaluation process.

Janna: How do you approach grants?

Jason: Over the years, I've sat on many, many juries both for individual artists and for galleries and festivals, and that's at every level of government, so on local, public art juries, on Ontario Arts Council juries and on Canada Council juries, so I've read a lot of grant applications over the years, and what I've noticed in general is that there's very little time - you know — when you've got a jury that's looking at three hundred applications what that jury is looking for is a clarity in the idea or the concept of an application, so the clearer that the writing is, I found, the more successful the rate of the application. You know, because then the jury can actually a conversation about the idea, because it's so clear. When things are unclear or littered with jargon that may not be 
universally understood by the jury, then it becomes a more-problematic granting request in the sense that it can't be evaluated properly.

Janna: Would you have a week to do that?

Jason: You get those applications ahead of time to read them before the jury sits, but going through a hundred or three hundred applications is pretty hard on the brain. You know - particularly organizational grants can be thirty pages long so you times that by however many applications there are. You know it's a challenge for jury members, so, as I mentioned, the clearer you are in your applications and the clearer you are about your intent, I think, the better chances that jury members can actually adjudicate your application properly. ... Again, there is nothing wrong with theory-laden work, but you need to find a way to communicate that clearly in an application. I think that really helps you.

Janna: How long would the jury meetings be?

Jason: A jury can last five full days where you go through every application. Sometimes it's alphabetical order or the order in which it was - the dates in which it was submitted. People have different systems, but you go through each application individually, and I find the ones that are sort of dismissed are the ones that aren't understood so there's less time spent on discussing those applications, because people don't understand them.

Jason highlights the importance of having an application that clearly conveys a concept and that is "universally understood by the jury." Reflecting on his experience serving on a number of juries locally, provincially and nationally, Jason makes explicit that proposals need to convey concepts clearly in order to be "evaluated properly" and in order for the jury to "actually have a conversation about the idea." He stresses the importance of having proposals that are clear as opposed to "when things are unclear or littered with jargon that may not be universally understood by the jury." While he refers here to juried application processes, his emphasis on conveying a concept connects well to curators' decision making work more generally. The conjunction between work and words is indeed striking in the ways that curators evaluate submissions.

When making decisions about who/what to show, curators also described paying attention to artists' reputations. One curator mentioned that, when making decisions, she "always 
look[s] at their CV." What she is "watching for" is gallery showings and educational credentials; these institutional certifications and awards appear as lines on the CV. She said that having an MFA indicates a "certain amount of perhaps conceptual seriousness in their practice. ... If they have an MFA, we certainly pay attention, because we know they have invested just that much more into really the seriousness of their practice." As this curator puts it, there is a dialectical relationship between "conceptual seriousness" and an MFA - which is both a sign of and a route to that seriousness. This is very much in line with artists' experiences that developing the "language tools to go with your practice" and being able to bring art and language together is the/one product of academic art training. This is also in line with Fatona's (2011) assertion that arts organizations often work to "weed out the categories of artists often referred to as 'Sunday painters' or 'amateur artists"” (p. 93). To draw on Bourdieu's (1984) notion of "symbolic capital," an artist's reputation is not determined by the work and words themselves but by the weight they carry and by the reputation that is earned through them and that also backs them up. And, "reputation" is not merely "what people think" of an artist; it is institutionally accomplished and is given textual presence.

It merits notice that curators are mindful of the possibility that words and reputations can fly away from the quality of the actual visual work itself. This is implicit in the quotations above in which Heather says that "first and foremost, the artwork has to be really interesting," and Jason says, "I think most people like to see work that speaks for itself." The possibility of words flying away from works is even more explicit in Jason's saying, with regard to materials sent to juries, "you're not impressing anyone by telling [them] something that the work is doing that is not clear when you look at it." Further, with regard to reputations, Heather Anderson offered this observation: 
I also see a phenomenon too from time to time. [I] see somebody become successful, achieving residencies and grants. It's almost like it builds upon itself. All those experiences or awards kind of endorse them by certain professionals. It's almost like it can carry on.

Heather points out an artist's awards can serve as endorsements, and that those can cascade, building on themselves. It may be that in saying these things curators are implicitly responding to critiques of idea-domination or text-heaviness that circulate within the art world.

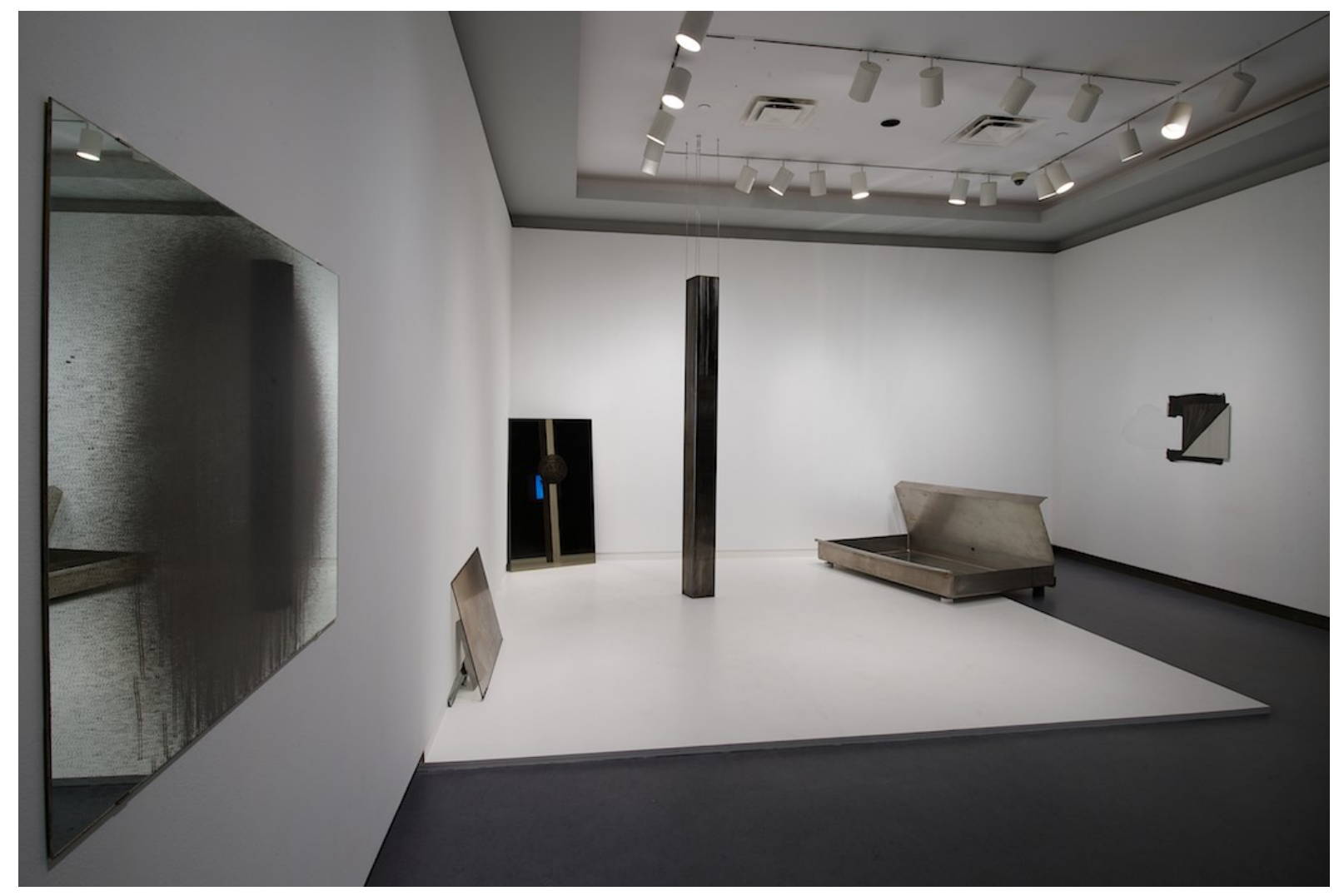

Figure 8. Jinny Yu, Ball; Studio Work Number 37; Ball; Column; Stalker; Painting, Painting, Painting, 2014, various dimension and materials, installed at Ottawa Art Gallery, courtesy of the artist.

\section{Expanding outwards... funding bodies, audiences, conversations, mandates}

Curators' conceptual practices involve not just looking at the conjunction between work/words and at the artist's reputation, but also at how the work/words/reputation bundle hooks into the larger conversation, into the discursive practices that circulate through the art regime beyond any one local site. The conjunction of work and words is not just about one work 
and the words pertaining, but about how that work and those words relate to other works and words. It's not just her art and her ideas about it, but her art and ideas as they fit into a larger conversation. The conversation includes diverse participants (e.g., art critics, academics, funders, audiences) and texts (e.g., funding applications, exhibition promotion materials, organizational mandates). Curators stitch artists' work/words/reputations into processes in the discursive art world that join up with immediate and distant others. Quoting Fynn Leitch again:

There are artists who hate the idea of anything written being in the gallery to quote unquote explain the work, right? They want to just stand behind the work, and present that as the final thing - I was going to say final word, but that's inappropriate - the only thing that the public requires. There's a problem though - or there's a tension, I should say, between that sort of purity, and the way that institutions exist in the system that has been created here. And, because of the system that's been created here, which invariably includes funding, and within that funding there's lots of expectations about engagement and outreach. There's lots of - whether it's pressure or interest in-ensuring that the public has multiple avenues into the work. So, one of those avenues is going to be the work itself - for sure, but often it's useful to have other ways for the public to engage with that. ... It's difficult for people to navigate that space. And, for some artists that's kind of the point, right? It's fun to create a work that might pull apart or might identify the difficulty of engaging with work or it might be something that's like "Well, you know, if they get it they get it, if they don't they don't." The problem is that institutions have to account for their efforts to engage the public and to educate the public. Because we're supporting the practice of art on a number of levels. One, you're supporting the artist by paying artist fees. You're supporting the art by presenting it - just like straight up physically presenting it; but also you have to support it by educating the public or just contributing to the conversation on Canadian art with your immediate audience that physically enters the space, but also on the internet. ... The intention of writing is not to patronize the work or detract from the work, but to create another avenue through which the public can access it. And, for the gallery itself to contribute, again, on its own, alongside the contemporary practice of art, to the critical practice about contemporary art.

In this remarkable description, Fynn highlights how curators' work in their galleries connects to work happening in other spheres. Differentiating between the "purity" of the art object as "the final thing" and "the way that institutions exist," she renders visible the work that curators do, which includes "expectations about engagement and outreach" that come with the funding (and those terms, "engagement and outreach," are terms used in funding agreements galleries enter 
into). The work as viewed within the curator's work process, is not "the final thing." It is taken up within "institutions" or "the system." So galleries are responsible for providing "avenues into the work," which may itself be "difficult." These "avenues" are provided for "the public," which may be the "immediate audience" in the gallery itself or people on the internet. And the "avenues" are not concerned merely with clarifying the potentially difficult work itself, but also with "educating the public" by bringing them into "the conversation on Canadian art. 5 " Heather Anderson related another aspect of engaging the public- less concerned with "educating the public" than with "meeting audience needs":

[Public funding bodies] also want to know an increasing amount of information about how you address the needs of community, and as you can imagine like all these kind of buzz words about community and reaching new audiences and the youth demographic. How do you make an impact? They want to know more and more about measurable outcomes. So, it's become more bureaucratic too, so it's this balance about writing about the art itself, but also it's more bureaucratic.

Heather explains that public funding bodies require curators to account for their efforts to address the needs of the community as well as reach new audiences and reach the youth demographic. They want to know about "measurable outcomes." As one curator put it, galleries

\footnotetext{
${ }^{5}$ The notion of "the public" is complex and variously used in the art world. Some curators referred to "reaching new audiences," appealing to different "demographics," and having "something there" for those at an "introductory level" and for those with "theoretical knowledge" who "want things pitched at that level." Curators made explicit that being "approachable to a wide-range of audiences" is part of how they get their funding. That said, some of the artists I interviewed had a more cynical take on the breadth of "the public." Beth McCubbin said, "In England, all the galleries are free. Absolutely everybody has been to the art galleries - like the big art galleries like The Saatchi or The Tate - because they're free. Here [in Canada] they cost 25 to like 50 dollars to go to shows, so nobody goes. I can't even go. That's a big deal. Or you can go to private galleries, but those are curated galleries, which is also intimidating. In England, when you're talking to people - just Average Joes - they have an opinion on art, because it's everywhere. Here, a lot of people have never even been in the gallery before, because it costs a lot of money. It really changes your general public, and your understanding." Along the same lines, Marika Jemma pointed out that "the non-specifically educated person" is not viewed as "an important part of the whole conversation" in the art world. She said, "What happens when you use highly specific language or language that is specific to a particular genre, is that you in essence alienate a good chunk of the populous who doesn't have an art background or doesn't have a certain level of academic education. They can't access that part of the conversation, so they can't have their own response."
} 
have to "justify their existence." One kind of justification comes with "reaching audiences," and this reach may have to be displayed as a measureable outcome.

In their work of educating and engaging the public, curators represent artists' work/words/reputations to audiences in a variety of texts, which can include press releases, brochures, posters, websites, didactic panels (a.k.a. writing on the wall), advertisements, reviews and catalogues. Curators typically refer to such writing as opening up the conversation, and engaging/educating the audience. In speaking about her own writing in this vein, Heather said:

you also want to bring new ideas and contribute something. Sometimes, I think, writing about an exhibition or an artist's work is a balance of sometimes being directly about that work and sometimes it's about creating some kind of parallel text or parallel discussion.

She emphasizes that there's a kind of delicacy in what might be thought of as the translation to this "parallel text" - and the ways that it both speaks to an audience, and expands outwards. Heather describes needing to present artists' work in a way that "doesn't close down meaning," and that isn't "too specific." She said, "There has to be space through what they say for you to imagine the work expanding outwards too, but, at the same time, you don't want something that's so vague or ambiguous."

In deploying conceptual practices, curators are responsible — not only for evaluating the work/words/reputations on their own, but for considering how the work/words/reputations speak to the Canadian art world. In Heather's expression of this discursive relation, artists' work should “expand outwards.” In making decisions about who/what to show, curators consider how artists' work/words/reputations will fit into the ongoing conversation. This conversation has a history (in the sense that "you don't want to just replicate shit" as one curator said) and a future (in the sense that topics/currents shift and that there is a "contemporary art now" as another curator mentioned). Catherine Sinclair's formulated this discursive relation as "contextualizing:" 
[You] bring it into the wider context so that you're contextualizing it. So, saying: This artist is looking at this. This is their perspective. Who else has looked at this? What other trends have been done? Where does this fit into the wider picture? Why are artists in general looking at this? What's her or his unique take on that issue? Bringing it in line with theory or, you know, current events or current issues within the art world that would be relevant.

So "contextualizing," as Catherine presents it, involves juxtaposing one artist's work with others, taking up what one artist "is looking at," and putting it into relation with other "perspectives," with "theory or ... current issues within the art world." Having an artist that fits into the art world in this way no doubt improves a gallery's chances of receiving media attention, of having the exhibition critically reviewed, and of finding channels to get out there (and into the world of critical art theory). Fynn Leitch mentioned:

I think it's really [important] for people to acknowledge their situation within the broader context of Canadian art practice, and broader to that, contemporary art practice. I think it's really integral; at least within the infrastructure that we have set up within Canada. Definitely for grants for artist practice, and for getting shows outside of commercial dealerships, it's really important to have an understanding of art history. It doesn't mean that you have to talk about that or that your work has to visibly display that knowledge; [but] it tends to be really obvious if you don't have that knowledge.

So Fynn again emphasizes the larger conversation, the broader context, specifically with regard to art history. She points out it isn't just about art-making, but about hooking art into a larger conversation. Artists need to situate their work within contemporary art practice.

It is also important to note, curators' conceptual practices involve looking at the work/words/reputations with a view to fitting them into their organizational mandate. Fynn said, "at the very fundamental level [curators] have to be acting for their mandate first." For example, Catherine Sinclair explained, "Our mandate is to showcase regional artists work from Ottawa Gatineau but within the context of National-International." Catherine makes explicit her mandated work to "put it all together," showing regional artists alongside artists with national or international reputations. While the priorities differ from gallery to gallery, the organizational 
mandate shapes curators' activities, giving them particular ways of rendering art/language.

Curators' conceptual practices involve not just looking at the conjunction between work/words and at the artist's reputation, but also at how the work/words/reputation fits into the larger “conversation," which includes other artists, art professionals, administrators, audiences and scholars working in studios, galleries, funding bodies and universities.

\section{Discussion}

This analytical chapter has examined how art and language conjoin in curators' work to make decisions about who/what to show. In exploring curators' conceptual practices, this chapter traced how curators watch for, promote and are responsible for showing work that is conceptual and reputable. Curators look at the work/words/reputations of artists with a view to fitting them into the larger conversation going on in the Canadian art world. These discursive connections call to mind Bakhtin's notion of dialogic discourse, which recognizes utterances as relational, living and in conversation with the past, present and future utterances of others (Bakhtin, 1981). Curators' conceptual practices point to a conversation that has a past, present and future, and that is institutionally organized across sites. The discursive character of this work is reminiscent of a Burkean parlour. As Burke (1941) puts it:

Imagine that you enter a parlour. You come late. When you arrive, others have long preceded you, and they are engaged in a heated discussion, a discussion too heated for them to pause and tell you exactly what it is about. In fact, the discussion had already begun long before any of them got there... You listen for a while, until you decide that you have caught the tenor of the argument; then you put in your oar. Someone answers; you answer him; another comes to your defense; another aligns himself against you, to either the embarrassment or gratification of your opponent, depending upon the quality of your ally's assistance. However, the discussion is interminable. The hour grows late, you must depart. And you do depart, with the discussion still vigorously in progress. (p. 110111) 
Within their Burkean parlour — the discursively ordered art world — curators put their oars in by hooking their own work and the work of artists into the larger conversation. Curators do not work in isolation or merely by their own lights. Curators aren't simply looking at the work and words of artists; they are also responsible for bringing artists' work and words into relation with various institutional and discursive processes, involving both immediate and far-flung others. And, this "conversation" is very much institutionally organized and textually coordinated in and through work of people across discursive sites.

While Balzar (2014) argues the curator "reigns supreme" in the modern art world, my own analysis complicates this insight. In tracing the institutionally coordinated and textually mediated work of curators, I find that much of their work and their conceptual practices are coordinated with and constrained by, while they take part in making up, the conversation. The professional authority curators display when selecting work that is conceptually serious or institutionally reputable is shaped in relation to work processes elsewhere. Their ways of interpreting aren't unique, interpretive mental processes, but are socially situated and socially organized. To call on Goodwin (1994), the "perceptual structures that organize interpretation ... are lodged within a profession and not an isolated individual" (p. 625). Their professional ability is discursively accomplished moment by moment in their coordinated work. While curators, of course, have professional objectives and knowledges (and do exercise professional authority), their work is connected to the larger discursive terrain. They actively and discursively shape (and are shaped by) the extended complex of interrelations of which they are a part. Their own work enacts the institutional art regime. 


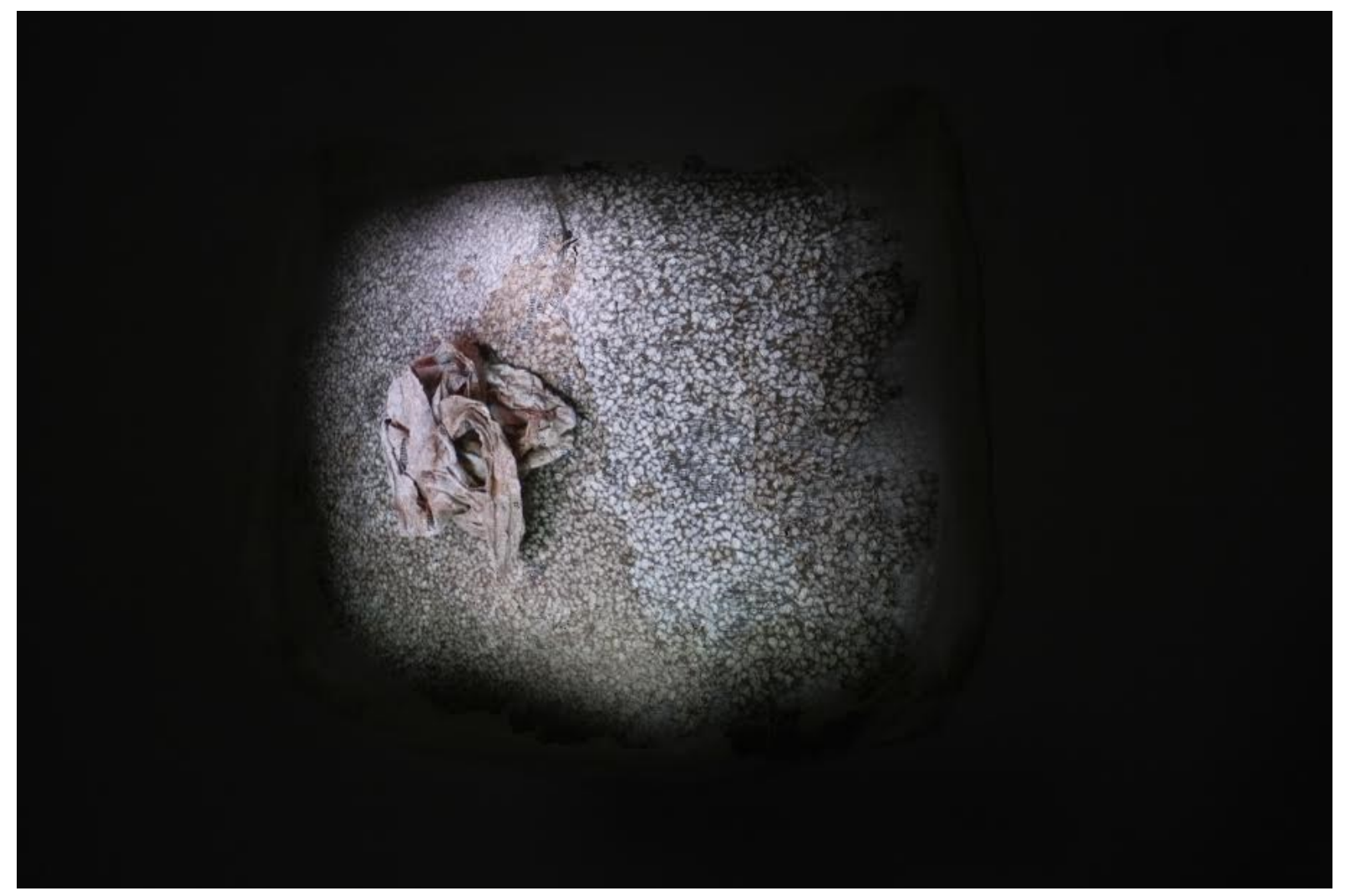

Figure 9. Sharon Katz, Manifest, 2013, installation still image, video projection on handmade paper, variable dimensions, courtesy of the artist. 


\section{Chapter 6: Conclusion}

How do we bring closure, expunge doubt, rid ourselves of disruptive retrospection, find the limits of concern? Perhaps we don't. - Richard G. Mitchell, (2002, p. 208).

This institutional ethnography has been an analytic effort to open up the art world and to map institutional workings across discursive sites. Aiming to explicate the institutional terrain, this project began with concerns about how contemporary workers are set up. More particularly, this project began with Beth's concerns about the way she has to justify herself in language, and about the way language has been squished on to the art world. Responding to Beth's concerns, this thesis examined visual artists' and curators' real work to participate in the institutional art regime through their ordinary material practices and embodied relations.

This thesis traced how artists and curators actively participate in the discursive and institutional relations of the art world. Doing art isn't only about dabbing paint or firing up the kiln nor is it about installing exhibitions that are a final product or a last word. Artists' and curators' work is about carving out space — physically and discursively — in the institutional art regime. To navigate the art world, they conjoin art and language while shaping (and being shaped by) extended social relations (of which they are a part). They do not speak from scratch nor do they speak in isolation. Instead, they perform the institution (in conceptual and reputable ways), coordinate with others, and hook themselves into the discursive and institutional relations of the art world.

In introducing institutional ethnography in Chapter 2, I mentioned that past studies found that textual technologies translate the actualities of people's real work into standardized, measurable and managerial forms (see Griffith \& Smith, 2014). Past studies have highlighted how people's actual work is being slotted into, subsumed by, and subjected to extra-local 
institutional work processes. Like many contemporary organizations, the modern art world is increasingly textually and institutionally coordinated. That said, while the art world is indeed institutional (and artists and curators alike work to discursively justify their existence), it is only in part conventionally bureaucratic. It is important to underscore, that there isn't a set template with standardized, quantifiable criteria for "conceptual" or "reputable" that curators are responsible for slotting artists and their work into. Curators don't carry clipboards with tick boxes. In the art world, there isn't some single elite that makes up objectifying categories and then issues diagnoses or administrative decisions. While curators do, of course, exercise professional judgement in their decision making work, much of the art world is coordinated in and through a larger conversation. Working artists are not only subject to judgment with regard to whether they contribute to the conversation, they also contribute to shaping, developing and changing the conversation.

Artists and curators alike talked about the conversation. Some talked about speaking to it, edging in, and moving from the periphery to the centre of it. The conversation, I learned, isn't simply about the critical theories of academe - nor is it simply about the measurable outcomes of public funding bodies. It is an array of connections, an array of practices and relations, an array of written and spoken utterances across various discursive realms. The conversation is intentional and intellectually rigorous. It's about framing and situating through the conjoining of work and words. Certain words with certain work. It's about concepts and ideas, and about contributing to the contemporary art world now. It's about conceptual seriousness. Seriousness, too. The conversation isn't about throwing colours together, and it isn't about intuition-unless you can account for how you're using intuition. The conversation is polished and removed. It isn't for Sunday painters, and it isn't about just stepping back from your work and going 
"Wow!" The conversation is tailored and directed. It's about professional standing-lines on a $\mathrm{CV}$, degrees, awards, and the number of times the work has been reviewed. It's about the tension between transforming the art institution and being accommodated by it (Dimitrakaki, 2013, p. 211). The conversation is about educating and engaging the public, and educating and engaging yourself. It's about developing the written and verbal component, finding the language to explicate and extrapolate. It's about contributing to public consciousness, putting forward ideas, and, at times, letting the work expand outwards to take on different meanings. The conversation is about knowing the rules - knowing enough to sign your full name, knowing enough not to replicate shit, and knowing that the chances of a cold call being accepted by a local gallery are few and far between. It's about removing the personal from your professional performances, distancing the artwork from the producer, and distancing the artwork (and your understanding of it) from your own whims. The conversation, for some, is alienating, intimidating and kind of like jumping through hoops. Yet others talked about $A$ ha moments where it clicked, about grasping the concepts, and about wrestling with and working through ideas. Some enjoyed the process, and viewed participating in the conversation as essential and respectable. Regardless of whether people participate by honouring the institution, by playing the game, or by poking fun at what may seem is absurdity, people are indeed putting together, enacting and bringing about the conversation moment by moment. They are shaping the conversation, shaping themselves, and shaping the extended complex of interrelations of which they are apart. Artists, too, put their oars into the discussion in the Burkean parlour. Diverse artists, curators, critics, professors and audiences engage in, and have (perhaps variously potent) opportunities to shape, the conversational parlour of the art world. Again, this conversation isn't happening to anyone-it is continually shaping (and being shaped by) those involved. The conversation happens in and 
through the continual, coordinated production of - and engagement with - materials, discourses, social relations, and institutions.

As a researcher, I didn't learn about the conversation from the safe distance of a lookout tower. Instead, I entered into it, bantered back and forth, tried to make sense of institutional happenings, and tried to understand how visual artists are set up. I see in retrospect that I did go in with an agenda-looking for a squish, and trying to pinpoint when, where and who that squish was coming from. While I had hoped to narrow in on a rot at the top (and to thereby also make sense of my own institutional exclusion), what I discovered is a conversation that, again, involves an array of connections, an array of practices and relations, an array of written and spoken utterances. It is complicated and varied; interconnecting and overlapping. It makes it hard to point a finger and hard to say what — if anything — I'd change, if I could. Attending to the conversation, though, I did come to see some experiences/knowledges being subsumed. It is important to underscore that the conversation often decentres people who don't frame (their) art in institutional terms. Within this increasingly institutionally and textually coordinated conversation, some experiences/knowledges are delegitimized. There are some experiences/knowledges that are harder to frame, legitimate or squeeze into the conversation.

As I traced the conversation, I came to see it isn't that some artists are flawed or that some curators are vicious. It is that the conversation - that artists hook into and that curators are responsible for hooking artists into — is not organized to accommodate certain people. Within this conversation, certain artists have vulnerabilities that curators must make up for. As one curator explained, if an artist doesn't have a formal education, then it is up to the curator to do the work: "There's a lot of galleries that are able to position the artists they show within a serious practice as well." Another said, if an artist doesn't have a formal education it's up to the curators 
"to play that supporting role," adding, "That said, I know I appreciate so much when an artist is articulate about their ideas." It isn't that curators themselves are edging out artists without formal training or without conceptual seriousness, it's that the conversation demands seriousness. The conversation - replete with its connections, currents and overlap-isn't organized to accommodate certain, less-serious, less-conceptual voices.

What, now? The invitation, I think, isn't to overthrow the conversation, put a grandiose dent in it or muzzle those who are doing the speaking. The analytical work of institutional ethnography can, however, contribute to the real work of disrupting oppressive processes (Campbell \& Gregor, 2002) and disrupting knowledge relations (G. Smith, 1990) through ordinary, on the ground efforts, and through opening up small fissures to make the lives of people, like my friend Beth McCubbin, more secure. My hope is that my research helps to nudge against the conversation, to carve out space for different voices and to broaden the tastes of the art world. That said, I acknowledge that change doesn't happen theoretically or metaphorically, but in ordinary and concrete ways as a part of people's actual work. In the world of conceptual, reputable and serious art, I push for funding categories and art opportunities that support those creating outside of the institutional gaze, those taking an expressivist approach, and those occasionally stepping back from their work and just going, "Wow!" I push for grant, gallery and travel opportunities for those who have devoted their lives to art-making and community organizing; to crafting sculptures in their kitchens, to lugging work up and down flights of stairs, and to suspending sculptures in alleyways. I push for channels of getting out there that don't always involve positioning work as conceptually serious and that don't always involve distancing work from the producer. As does any institutional ethnographer, I push for more research that shines a light on contemporary knowledge regimes. I push for research that starts 
with mundane, day-to-day practices and then traces outward to explore how experience is institutionally coordinated. I push for research that begins not in the abstract world of theory, but in conversation with people about their experiences_-listening in and learning about the ordinary ways people shape, and are shaped by, the institutions they are part of. I push for change from below. 


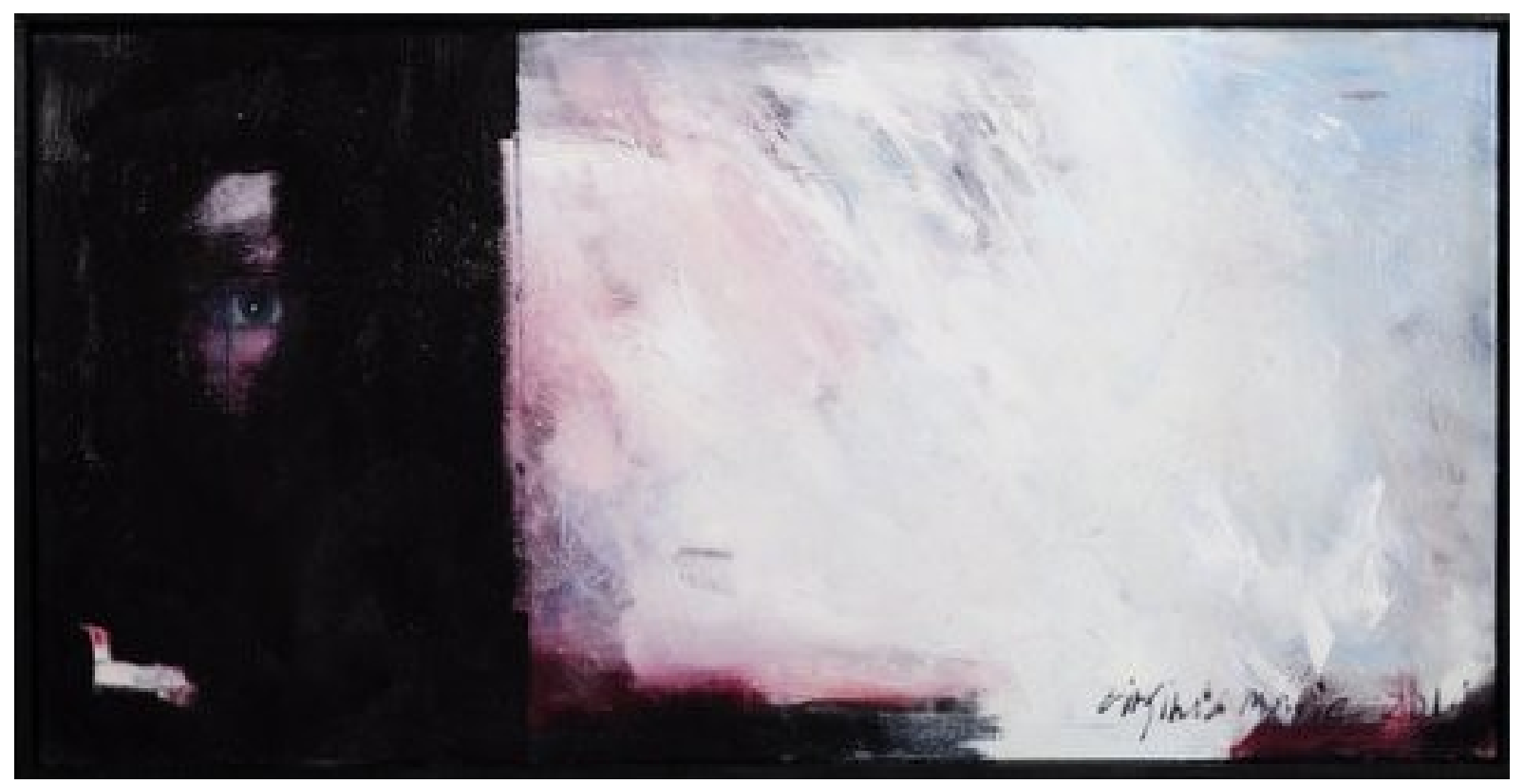

Figure 10. Virginia Marie, Abandoner, 2014, oil on canvas, 18 x 36 inches, courtesy of the artist. 


\section{References}

Bakhtin, M.M. (1981). The dialogic imagination: four essays. (M. Holquist, Ed.; C. Emerson \& M. Holquist, Trans.). Austin, TX: University of Texas Press.

Bakhtin, M.M. (1986). Speech genres and other late essays. Trans. by Vern W. McGee. Austin, TX: University of Texas Press.

Bain, A. L. (2004). Female artistic identity in place: the studio. Social \& cultural geography, 5(2), 171-193.

Balzer, D. (2014). Curationism: how curating took over the art world and everything else. Toronto: Coach House Books.

Blakenfeld, K., von Zeppelin, C., \& Adams, S. (2009). “Top Billionaire Art Collectors.” Forbes. Retrieved from: http://www.forbes.com/2009/07/24/top-billionaire-art-collector-picassogeffen-rich-lifestyle.html

Burke, K. (1941). The philosophy of literary form. Berkeley: University of California Press.

Campbell, M. (2006). Institutional ethnography and experience as data. In Dorothy E. Smith (Ed.), Institutional ethnography as practice (pp. 91-108). New York: Rowman and Littlefield Publishers.

Campbell, M., \& Gregor, F. (2002). Mapping social relations: A primer in doing institutional ethnography. Toronto: Garamond Press.

Darville, R. (1995). Literacy, experience, power. In Marie Campbell and Ann Manicom (Eds.), Knowledge, experience and ruling relations: Studies in social organization of knowledge (pp.249-61). Toronto: University of Toronto Press. 
Darville, R. (2009). Literacy as practices, teaching as alignment: A message in a bottle. Literacies: Researching Practice, Practising Research, 10, 14-18.

Darville, R. (2014). Literacy work and the adult literacy regime. In Alison I. Griffith and Dorothy E. Smith's (Eds.), Under new public management: Institutional ethnographies of changing front-line work. Toronto: University of Toronto Press.

Diamond, T. (2006). Where did you get the fur coat, Fern? In Dorothy E. Smith (Ed.), Institutional Ethnography as Practice, 45-64. Lanham, MD: Rowman \& Littlefield.

de Montigny, G. (1995a). Social working: An ethnography of frontline practice. Toronto: University of Toronto Press.

de Montigny, G. (1995b). The power of being professional. In Marie Campbell and Ann Manicom (Eds.), Knowledge, experience and ruling relations (pp. 209-220). Toronto: University of Toronto Press.

DeVault, M. L. (2008). People at work: Life, power, and social inclusion in the new economy. New York: New York University Press.

Dimitrakaki, A. (2013). Gender, artwork and the global imperative: A materialist feminist critique. Manchester University Press.

"Dorothy Caldwell." (n.d.). Dorothy Caldwell: Silent Ice | Deep Patience. Art Gallery of Peterborough. Retrieved 1 April 2015: http://agp.on.ca/exhibitions/dorothy-caldwellsilent-ice-deep-patience/

Eastwood, L. (2005). The social organization of policy: An institutional ethnography of UN forest deliberations. New York: Routledge. 
“Enriched Bread Artists.” (n.d.). Marika Jemma. Enriched Bread Artists. Retrieved 15 November 2014: http:/www.enrichedbreadartists.com/members/jemma.htm

Fatona, A.M. (2011). “Where outreach meets outrage”: Racial equity at The Canada Council for the Arts (1989 to 1999). Doctoral dissertation, University of Toronto.

Fraser, A. (2012, February). "1\% Art: Who are the patrons of contemporary art today?" Adbusters. Retrieved from: https:/www.adbusters.org/magazine/100/1-percent-art.html

Garrett-Petts, W.F., \& Nash, R. (2009). “Re-Visioning the visual: Making artistic inquiry visible.” In Craig Saper, W.F. Garrett-Petts, and John Craig Freeman (Eds.), Rhizomes, 18. Retrieved 1 April 2015: http://www.Rhizomes.net

“General Hardware.” (n.d.). Jinny Yu. General Hardware Contemporary. Retrieved 1 April 2015: http://generalhardware.ca/jinny-yu/

Goodwin, C. (1994). "Professional vision.” American Anthropologist, 96(3): 606-633.

Griffith, A. \& Smith, D.E. (2014). Under new public management: Institutional ethnographies of changing front-line work. Toronto: University of Toronto Press.

Gutiérrez, K. D. (2008). Developing a sociocritical literacy in the third space. Reading Research Quarterly, 43(2), 148-164.

Harris, R. (2003). Necessity of artspeak: The language of arts in the western tradition. A\&C Black. 
Jan, S. (2014). For-profit contractors, accreditation, and accountability. In Alison I. Griffith and Dorothy E. Smith (Eds.), Under new public management: Institutional ethnographies of changing front-line work. Toronto: University of Toronto Press.

Kerr, L. (2014). E-governance and data-driven accountability: OnSIS in Ontario Schools. In Alison I. Griffith and Dorothy E. Smith (Eds.), Under new public management: Institutional ethnographies of changing front-line work. Toronto: University of Toronto Press.

Lewis, W. (1954). The demon of progress in the arts. London: Methuen.

McCoy, L. (2014). "If our statistics are bad we don't get paid:” Outcome measures in the settlement sector. In Alison I. Griffith and Dorothy E. Smith (Eds.), Under new public management: Institutional ethnographies of changing front-line work. Toronto: University of Toronto Press.

McCoy, L. (1998). Producing “what the deans know”: Cost accounting and the restructuring of postsecondary education. Human Studies, 21, 395-418.

McCubbin, B. (n.d.). About Beth. Beth McCubbin. Retrieved 1 April 2015: https://bethmccubbin.wordpress.com/

Mitchell, R. G. (2002). Dancing at Armageddon: Survivalism and chaos in modern times. Chicago: University of Chicago Press.

Nichols, N. (2014). Youth work: An institutional ethnography of youth homelessness. Toronto: Toronto University Press. 
Nichols, N. E. (2011). "All my life I've slipped through the cracks.": The social coordination of youth work. Doctoral dissertation, York University.

Nochlin, L. (1971). Why have there been no great women artists?. The feminism and visual culture reader, 229-233.

Porter, M. (n.d.). Bio/CV. Mary Porter. Retrieved 1 April 2015: http://www.maryporter.ca/bio.html

Plattner, S. (1996). High art down home: An economic ethnography of a local art market. University of Chicago Press.

Rankin, J. \& Campbell, M. (2006). Managing to nurse: Inside Canada's health care reform. Toronto: University of Toronto Press.

Rankin, J. \& Tate, B. (2014). Digital era governance: Connecting nursing education and the industrial complex of healthcare. In Alison I. Griffith and Dorothy E. Smith (Eds.), Under new public management: Institutional ethnographies of changing front-line work. Toronto: University of Toronto Press.

Roubini, N. (2015, February 11). Why art is an asset class. Nouriel Unplugged - EconoMonitor. Retrieved from http://www.economonitor.com/nouriel/2015/02/11/why-art-is-an-assetclass/

Rule, A., \& Levine, D. (2012). International art english. Triple Canopy. Retrieved from http://canopycanopycanopy.com/issues/16/contents/international_art_english

Rusted, B. (2006). Performing visual discourse: Cowboy art and institutional practice. Text and Performance Quarterly, 26(2), 115-137. 
Schegloff, E.A., \& Sacks, H. (1973). Opening up closings. Semiotica, 8(4), 289-327.

Sefton, T.G. (2006). Master of Fine Arts: The Construction of the Artist in Academe. Doctoral dissertation, University of Toronto (Canada).

Sinding, C. (2014). Institutional circuits in cancer care. In Alison I. Griffith and Dorothy E. Smith (Eds.), Under new public management: Institutional ethnographies of changing front-line work. Toronto: University of Toronto Press.

Smith, D.E. (1987). The everyday world as problematic: A feminist sociology. Toronto: University of Toronto Press.

Smith, D.E. (1989). Feminist reflections on political economy. Studies in Political Economy, 30: 37-59.

Smith, D.E. (1990a). “On Sally L. Hacker's method.” In Sally L. Hacker, “Doing it the hard way:" Investigations of gender and technology (edited by Dorothy E. Smith and Susan M. Turner). Boston: Unwin Hyman, 1-17.

Smith, D.E. (1990b). Texts, facts and femininity: exploring the relations of ruling. London: Routeledge.

Smith, D.E. (1990c). The conceptual practices of power: A feminist sociology of knowledge. Toronto: University of Toronto Press.

Smith, D.E. (1999). Writing the social, critique, theory, and investigations. Toronto: University of Toronto Press.

Smith, D.E. (2005). Institutional ethnography: A sociology for people. Lanham, MD: AltaMira. 
Smith, D.E. (2006). Institutional ethnography as practice. Lanham, MD: Rowman \& Littelfield.

Smith, D.E. (2007). Making change from below. Socialist Studies/Etudes Socialistes, 3(2): 7-30.

Smith, D.E. \& Turner, S.M. (Eds.). (2014). Incorporating texts into institutional ethnographies. Toronto: University of Toronto Press.

Smith, G. (1990). Political activist as ethnographer. Social Problems, 37: 629-48.

Thornton, S. (2008). Seven days in the art world. London: Granta.

“Upcoming Exhibitions.” (n.d.). Upcoming Exhibitions - Human Nature. Carleton University Art Gallery. Retrieved 10 April 2015: http://cuag.carleton.ca/index.php/exhibitions/upcoming/

Voloshinov, V. N. (1986). Marxism and the philosophy of language. Cambridge, MA: Harvard University Press.

Winterson, J. (1995). Art objects: Essays on ecstasy and effrontery. London: Random House.

Wright, S. (2014). Knowledge that counts: points systems and the governance of Danish universities. In Alison I. Griffith and Dorothy E. Smith (Eds.), Under new public management: Institutional ethnographies of changing front-line work. Toronto: University of Toronto Press. 


\title{
Appendix A: Ethics clearance form
}

S Carleton

Canada's Capital University

\author{
Carleton University \\ Research Ethics Office \\ Research Ethics Board \\ $509 \mathrm{C}$ and 511 Tory, 1125 Colonel By Drive \\ Ottawa, ON K1S 5B6 Canada \\ Tel: $613-520-2517$, ethics $@$ carleton.ca
}

\section{Ethics Clearance Form - New Clearance}

This is to certify that the Carleton University Research Ethics Board has examined the application for ethical clearance. The REB found the research project to meet appropriate ethical standards as outlined in the Tri-Council Policy Statement: Ethical Conduct for Research Involving Human, 2 nd edition, and the Carleton University Policies and Procedures for the Ethical Conduct of Research.

Date of Clearance: August 29, 2014

Researcher: Janna Klostermann (Student Research: Master's Student)

Department: Faculty of Arts and Social SciencesILinguistics and Applied Language Studies (School of) University: Carleton University

Research Supervisor (if applicable): Prof. Graham Smart and Prof. Richard Darville

Project Number: 101996

Alternate File Number (if applicable):

Project Title: Authenticating an artistic identity: An ethnography of professional visual artists

Clearance Expires: May 31, 2015

All researchers are governed by the following conditions:

Annual Status Report: You are required to submit an Annual Status Report to either renew clearance or close the file. Failure to submit the Annual Status Report will result in the immediate suspension of the project. Funded projects will have accounts suspended until the report is submitted and approved.

Changes to the project: Any changes to the project must be submitted to the Carleton University Research Ethics Board for approval. All changes must be approved prior to the continuance of the research.

Adverse events: Should a participant suffer adversely from their participation in the project you are required to report the matter to the Carleton University Research Ethics Board. You must submit a written record of the event and indicate what steps you have taken to resolve the situation.

Suspension or termination of clearance: Failure to conduct the research in accordance with the principles of the Tri-Council Policy Statement: Ethical Conduct for Research Involving Humans, 2nd edition and the Carleton University Policies and Procedures for the Ethical Conduct of Research may result in the suspension or termination of the research project.

Andy Adler

Chair, Carleton University Research Ethics Board
Louise Heslop

Vice-Chair, Carleton University Research Ethics Board 


\section{Appendix B: Consent form}

\section{Carleton}

U N I V E R S I T Y

Canada's Capital University

Title: Authenticating an artistic identity: An ethnography of Canadian visual artists

Date of ethics clearance: 29 August 2014

Date that ethics clearance expires: 31 May 2015

This consent is for your participation in a research study that is looking at the work and identity-formation of visual artists. This study aims to examine writing in one corner of the Canadian art world from the standpoints of visual artists themselves, gallery curators, grant administrators, jury members and art writers.

The researcher for this study is Janna Klostermann in the Applied Linguistics and Discourse Studies program at Carleton University. She is working under the supervision of Prof. Richard Darville and Prof. Graham Smart in the Applied Linguistics and Discourse Studies program (School of Linguistics and Language Studies) at Carleton University.

As a participant in the study, you will take part in at least one audio-recorded interview of approximately 60 minutes. The interviews will take place on the phone or in a mutually convenient location. I will also invite you to contribute copies of key texts, including artist statements, CVs, grant applications, and other correspondence prior to the interview.

This project does involve some professional and emotional risks. You may feel embarrassed or upset when sharing about your work and your writing. As this project will ask you about your work, there are some professional and economic risks if you make statements that are critical of others. While risks are expected to be minimal, you have the option of requesting that certain responses not be included in the findings, and you may refuse to answer any question.

You have the option (a) having your identity anonymous and your responses nonattributable in materials related to the study (with the understanding that images of your art will not be included); or (b) being identified and having your responses and data attributable to you in materials related to the study (with the understanding that, with your consent, images of your art may be included). If you consent to (b) being identified and having your responses and data attributable to you, you will have the option of using your full name.

You have the right to end your participation in the study at any time, for any reason, up until 1 March 2015. You can withdraw by contacting the researcher or the research supervisor. If you withdraw from the study, you will be presented with the option of having all information you provided immediately destroyed.

The data gathered for this study will be used for research purposes related to the study (i.e., final thesis, conference papers, publications). The data will be stored on the researcher's password-protected USB-drive in a locked cabinet in the researcher's 
home. The audio recordings and notes will only be easily accessible to the researcher and research supervisors. Once the project is completed, all research data will be kept for a maximum of five years and potentially used for other research projects on this same topic. At the end of five years, all research data will be securely destroyed. (Electronic data will be erased and hard copies will be shredded.)

As a token of appreciation, you will receive a gift card to a local coffee shop. This is yours to keep, even if you withdraw from the study. Should you wish, I will also be happy to share the results of the study with you.

This project was reviewed by the Carleton University Research Ethics Board, which provided clearance to carry out the research. Should you have questions or concerns related to your involvement in this research, please contact:

\section{REB contact information:}

Professor Andy Adler, Chair Professor Louise Heslop, Vice-Chair

Carleton University Research Ethics Board

[contact information removed]

\section{Researcher contact information:}

Janna Klostermann

Applied Linguistics \& Discourse Studies

Carleton University

[contact information removed]

\section{Supervisor contact information:}

Graham Smart; Richard Darville

Applied Linguistics \& Discourse Studies

Carleton University

[contact information removed]

(a)Do you opt to have your identity anonymous and your responses non-attributable (with the understanding that images of your art will not be included in materials related to the study)?

Yes No

(b)Do you consent to being identified and having your responses and data attributable to you (with the understanding that, with your consent, images of your art may be included in materials related to the study)?

Yes No

If yes to (b), do you consent to being identified by your full name in materials related to the study?

Yes No

$\mathrm{I}$, have read the information above, have been given an opportunity to discuss it with the researcher, and any questions I had have been answered satisfactorily. I hereby consent to participate in the study and to have my interview digitally recorded.

Signature of participant

Date

Signature of researcher

Date 


\section{Appendix B: Exhibition materials}

The Carleton University Art Gallery included the following text for their exhibition, "Human

Nature" (27 April 2015 to 23 August 2015):

Artists featured: Mary Anne Barkhouse (Minden), Panya Clark Espinal (Toronto), John Dickson (Toronto), Soheila Esfahani (Waterloo), FASTWÜRMS (Creemore), Martin Golland (Ottawa), Sherri Hay (Toronto), Kelly Jazvac (London), Gareth Lichty (Kitchener), Gavin Lynch (Ottawa), Lisa Myers (Port Severn), David Ruben Piqtoukun (Sutton West), Su Rynard (Toronto), TH\&B (Hamilton)

Human Nature presents fourteen contemporary Ontario artists whose works look at the state of the natural world and our impact on it. Playing on the idea of human nature as a force that exploits and innovates, creates and destroys, the artists explore a range of such critical issues as food production, habitat loss, post-industrialization, and natural disaster. Taken together, the works of these artists reflect on human constructions and the complex interconnections between nature, culture, and technology. Human Nature is presented in collaboration with the National Arts Centre's Ontario Scene. ("Upcoming exhibitions," n.d.).

The Art Gallery of Peterborough included the following text for the show, "Silent Ice | Deep

Patience" (21 March 2014 to 22 June 2014):

This new body of work developed by senior artist Caldwell continues her exploration of place, how we mark the land, and how it is visualized in mapping practices, both conventional and personal. The scope of her research included extensive travel in both the Australian Outback and the Canadian Arctic. There are strong parallels between Canada and Australia and how they each imagine themselves. Both have large central wilderness landscapes, and are technically both deserts. The Outback and the Arctic are harsh landscapes that the indigenous populations have learned to survive in. They are both powerful landscapes that inspire the imagination and the way we view the country.

"The works for the exhibition will be a response to these experiences and how they relate to my own sense of place. Ultimately one comes back to the familiar landscape with renewed perspective and ongoing questions about interpreting images and values of another culture in light of our own experience."

Caldwell maintains an active international exhibition and teaching schedule from her studio in Hastings, Ontario. Her travel and research in India, Japan, and Australia have influenced her work both as sources of dyeing and stitching practices and as places where textile artists share her beliefs in the integration of historical work in contemporary contexts. Caldwell has been recipient of the Saidye Bronfman Award.

She has executed major architectural commissions, and her work is in many permanent collections including the Museum of Art and Design in New York, the Canadian Museum 
of Civilization, the Canadian Department of Foreign Affairs, the Museum of Fine Arts Boston, and the Art Gallery of Peterborough.

Silent Ice | Deep Patience is an AGP touring exhibition and will be accompanied by a publication. ("Dorothy Caldwell," n.d.). 